\title{
The Secured Creditor's Complaint: Relief from the Automatic Stays in Bankruptcy Proceedings*
}

\author{
Larry Peitzman $\dagger$ \\ Margaret S. Smith $\dagger$ †
}

Secured creditors are automatically stayed from foreclosing against debtors who commence proceedings under the Bankruptcy Act. To reach the security, the creditor must file a complaint with the bankruptcy court. The authors discuss the factors that courts generally consider in determining whether to grant the creditor relief from the stay, and suggest a limitation to the scope of defenses and counterclaims that a debtor may raise in opposing relief. The Article concludes with a redrafting of the automatic stay provision of the proposed bankruptcy legislation.

It is a rare creditor who makes a loan or sale of property expecting the debtor to go bankrupt. But it is a fact of life that some businesses are not healthy, and either expire or convalesce under the watchful eye of the bankruptcy court. To protect against such contingencies, a creditor often seeks to have the debtor's obligations secured by an interest in the debtor's real or personal property. The creditor assumes that if the debtor fails to honor the obligations, the security will always guarantee satisfaction of the debt. ${ }^{1}$ When the debtor files a petition

* The authors wish to express their gratitude to Professor William T. Laube and Patrick A. Murphy for their assistance and encouragement. The research for Part VI of this Article was originally prepared for the use of the American Bankers Association Task Force on Bankruptcy.

$\dagger$ B.A. 1969, University of California, Riverside; M.A. 1970, Harvard University; J.D. 1974, Boalt Hall School of Law, University of California, Berkeley. Member of the California Bar.

if B.A. 1970, M.A. 1972, University of California, Davis; J.D. 1976, Boalt Hall School of Law, University of California, Berkeley. Member of the California Bar.

1. It has long been recognized that the secured creditor has a property interest in his collateral protected by the fifth amendment to the Constitution. Wright v. Union Cent. Life Ins. Co., 311 U.S. 273 (1940); Wright v. Vinton Branch of the Mountain Trust Bank, 300 U.S. 440 (1937); Louisville Joint Stock Land Bank v. Radford, 295 U.S. 555 (1935); In re Penn Cent. Transp. Co. (Columbus Option), 494 F.2d 270 (3d Cir.), cert. denied, 419 U.S. 883 (1974); see Murphy, Restraint and Reimbursement: The Secured Creditor in Reorganization and Arrangement Proceedings, 30 Bus. LAW. 15 (1974) [hereinafter referred to as Murphy, Restraint]. But see Countryman, Real Estate Liens in Business Rehabilitation Cases, 50 AM. BANKR. L.J. 303, 334-39 (1976) [hereinafter cited as Countryman]. 
under the Bankruptcy Act, however, the creditor soon discovers that "always" often means later. Under the Bankruptcy Act and Rules, ${ }^{2}$ the creditor may be automatically stayed from realizing the value of the security. ${ }^{3}$ In order to obtain relief from the stay, the secured creditor must register a complaint with the bankruptcy court. This procedure raises issues mvolving the summary jurisdiction of the bankruptcy court and its power, as a court of equity, to enjoin interference with its administration.

Parts I and II of this Article will discuss relief from stays in straight bankruptcy and Chapter proceedings respectively. The issues that should be raised by a secured creditor seeking relief from an existing stay in Chapter proceedings and the evidentiary standards that should apply are the subject of Part III. In Part IV, the issues that may be raised by a debtor opposing the creditor's request for rehef will be examined. Part $\mathrm{V}$ deals with the order issued by the court vacating or modifying the stay. Finally, the authors suggest a revision of the automatic stay provision contained in the newly proposed bankruptcy legislation.

\section{I}

\section{ReLIEF FROM THE Stay Against LIEN ENForCEMENT in STRAight Bankruptcy Cases}

Whenever the debtor goes imto straight bankruptcy, it is a relatively simple matter for a secured creditor to realize the value of the security. If the creditor is in possession of the collateral at the time the debtor initiates bankruptcy proceedings-for example, if the creditor is a pledgee-then the bankruptcy may be disregarded and enforcement proceedings commenced. ${ }^{4}$ The court may not interfere because, in straight bankruptcy proceedings, the court's summary jurisdiction extends only to matters involving property of the bankrupt that

2. 11 U.S.C. §§ 1-1255 (1970). Proceedings under the Bankruptcy Act may either be "straight" bankruptcy proceedings under Chapters I through VII of the Act, the purpose of which is to liquidate a debtor's non-exempt assets for the benefit of creditors, or they may be rehabilitation or so-called "Chapter" proceedings, under either Chapter VIII (railroad reorganization), IX (municipal reorganization), X (corporate reorganization), XI (general business arrangement), XII (real property arrangeinent), or XIII (wage earner arrangement), the purpose of which is not to liquidate but to revitalize a debtor financially. See D. Cowans, BankRuptcy LAW AND Practice, $\$ 12$ (1963).

3. Bankruptcy Act $\S \S 148,311,314,411,414,611$, and 614,11 U.S.C. $\S \S 548$, $711,714,811,814,1011$ and 1014 (1970); BANKRUPTCY RULES 401, 601, 8-501, 9-4, 10-601, 11-44, 12-43, 13-401. See also Mueller v. Nugent, 184 U.S. 1 (1902).

4. In re Hudson River Navigation Corp., 57 F.2d 175 (2d Cir. 1932). 
is in the bankruptcy court's actual or constructive possession. ${ }^{6}$ A mortgatee who has commenced judicial foreclosure proceedings prior to the filing of the bankruptcy petition ordinarily may continue those proceedings despite the debtor's bankruptcy. ${ }^{\circ}$ A creditor inay enforce an attachment, judgment, levy or similar lien if that lien was obtained more than four months prior to the initiation of the bankruptcy proceedings. ${ }^{7}$

If the debtor has either actual or constructive possession of the security at the time bankruptcy proceedings are commenced, however, custody passes to the bankruptcy court, ${ }^{8}$ and the bankruptcy petition acts as a stay of hen enforceinent. ${ }^{9}$ This long-established principle of bankruptcy administration is now expressly included in the automatic stay provisions of Bankruptcy Rule 601. ${ }^{10}$ Rule 601 also adopts another long-established principle: The filing of a bankruptcy petition stays enforcement of all nonconsensual liens obtained within four months prior to that filing. ${ }^{11}$

The stay provided by Rule 601 remains effective until the bankruptcy case is dismissed or closed, or until the property subject to the lien passes from the control of the court. ${ }^{12}$ A secured creditor subject to the stay may, however, obtain an expedited determination as to whether the stay should be continued by commencing an adversary pro-

5. Thompson v. Magnolia Petroleum Co., 309 U.S. 478 (1940).

6. Murphy v. Bankers Commercial Corp., 203 F.2d 645 (2d Cir. 1953). While commencement of a bankruptcy proceeding will not oust state court jurisdiction over property in a mortgage foreclosure proceeding, the bankruptcy court may temporarily stay prosecution of the state court suit under Bankruptcy Act $\$ 11 \mathrm{a} .5$ H. REMINoToN, BANKRUPTCY $\$ \$ 2054,2056$ (5th ed. 1953).

7. Straton v. New, 283 U.S. 318 (1931); 5 H. Remington, Bankruptcy $\$ 2070$ (5th ed. 1953).

8. Ex parte Baldwin, 291 U.S. 610 (1934); Chicago Bd. of Trade v. Johnson, 264 U.S. 1 (1924).

9. Issacs v. Hobbs Tie \& Timber Co., 282 U.S. 734 (1931). "[T]he filing of the petition is a caveat to all the world, and in effect an attachment and injunction." Mueller v. Nugent, 184 U.S. 1, 14 (1902).

10. Rule 601 (a) provides that:

Stay Against Lien Enforcement. The filing of a petition shall operate as a stay of any act or the commencement or continuation of any court proceeding to enforce (1) a lien against property in the custody of the bankruptcy court, or (2) a lien against the property of the bankrupt obtained within 4 months before bankruptcy by attachment, judgment, levy, or other legal or equitable process or proceedings.

11. BANKRUPTCY RULE 601(a)(2). A lien obtained within four months before bankruptcy by judicial process or proceedings is voidable under $\$ 67(\mathrm{a})$ of the Bankruptcy Act if it is shown that the debtor was insolvent when the lien was obtained. Bankruptcy Act $\$ 67(a)(1), 11$ U.S.C. $\& 107(a)(1)$ (1970). The stay provided in Rule 601(a)(2) is said to be necessary to "prevent the frustration of the purpose of $\$ 67$ a by a transfer of the property subject to the voidable lien to a bona fide purchaser." Advisory Committee's Note to Bankruptcy Rule 601, 2 BANKRUPTCY ACT AND Rules 906 (Collier Pamphlet Ed. 1976).

12. BANKRUPtCY RULe 601(b). 
ceeding ${ }^{13}$ pursuant to Rule $601(\mathrm{c}) .{ }^{14}$ Assuming that the creditor's security interest is valid, ${ }^{15}$ there is only one important issue to be decided by the court under such a complaint: Does the value of the creditor's collateral exceed the amount of the secured indebtedness? If the answer is affirinative, there is equity in the property which ought to be realized by the trustee in bankruptcy for the benefit of the estate's unsecured creditors. ${ }^{16}$ If the answer is negative, there is no equity and the property should be abandoned by the trustee ${ }^{17}$ who is not "a liquidating agent for secured creditors."18 Thus, in straight bankruptcy proceedings, the court's task on a complaint for relief from the automatic stay agaimst lien enforcement is inerely to determine whether or not there exists equity in the secured creditor's collateral for the benefit of the general estate. ${ }^{19}$

\section{II}

\section{Injunctive Relief in Chapter Proceedings}

In contrast to straight bankruptcy, the court's task in rehabilitative proceedings is much more complicated. First, because different pohicies prevail in the rehabilitation chapters as compared to straight bankruptcy, ${ }^{20}$ the existence of equity in the collateral is only one of

13. See BANKRUPTCY RULES 701-82, which set forth the scope and procedures for adversary proceedings.

14. BANKRUPTCY RULE 601(c):

Relief from Stay. On the filing of a complaint seeking relief from a stay provided by this rule, the bankruptcy court shall, subject to the provisions of subdivision (d) of this rule, set the trial for the earliest possible date, and it shall take precedence over all matters except older matters of the same character. The court may, for cause shown, terminate, annul, modify, or condition such stay. A party seeking continuation of a stay against lien enforcement shall show that he is entitled thereto.

In extraordinary circumstances, where the secured creditor can show it will suffer immediate and irreparable injury as a result of the stay, ex parte relief may be available. BANKRUPTCY RULE 601(d).

15. Whether the debtor may challenge the validity of the creditor's security interest by raising affirmative defenses and counterclaims at the hearing for relief from the stay is discussed in Part IV infra.

16. See Southwestern Lumber Co. v. Kerr, 11 F. Supp. 252 (S.D. Tex. 1934), aff'd, 78 F.2d 348, cert. denied, 296 U.S. 611 (1935).

17. In re Ira Hanpt \& Co., 398 F.2d 607 (2d Cir. 1968). See Heffron v. Western Loan \& Bldg. Co., 84 F.2d 301 (9th Cir.), cert. denied, 299 U.S. 597 (1936).

18. Paskay, Some Procedural Aspects of Administering Encumbered Properties and The Treatment of Secured Creditors in Ordinary Bankruptcy, 44 REF. J. 54, 58 (1970).

19. Determining whether the debtor has equity in the property may, however, be difficult. For a discussion of valuation problems, see text accompanying notes 123152 infra.

20. The rehabilitation chapters (X, XI, XII) may be broadly characterized as debtor relief provisions. The goal is to rehabilitate the debtor's finances and avoid liquidation of the assets. Thus, if collateral that secures a debt is essential to a continuation of the business, successful rehabilitation may require that foreclosures be prevented. 
four issues that the court may consider in determining whether to grant relief from the automatic stay. ${ }^{21}$ Second, difficult jurisdictional questions arise which are important in determining both the scope of the court's mjunctive power (which includes both the power to issue and the power to continue the stay) and the extent to which a debtor may raise affirmative defenses and counterclaims in opposing relief from the stay. ${ }^{22}$ Before considering the four primary issues, these jurisdictional questions will be discussed.

In examining the court's jurisdiction, a distinction must be made between the bankruptcy court's power to suminarily adjudicate a party's substantive rights and its power, as a court of equity, to restrain and enjoin actions that might interfere with the rehabilitative purposes of Chapter proceedings. This distinction is often forgotten in the controversy over whether the bankruptcy court's summary jurisdiction is broader in rehabilitation proceedings under Chapters X, XI and XII than under the straight bankruptcy provisions of the Act. Determining the scope of summary jurisdiction has led both to disagreement between the two leading treatises on bankruptcy law and to inconsistent results in the Court of Appeals for the Ninth Circuit. ${ }^{28}$ The apparent source of confusion is the language of sections 111,311 and 411 of the Bankruptcy Act, which grant the bankruptcy court in Chapters X, $\mathrm{XI}$ and XII exclusive jurisdiction of the debtor and the debtor's property, wherever located. ${ }^{24}$

According to the Remington treatise, the scope of a bankruptcy court's summary jurisdiction to adjudicate substantive rights is no greater in Chapter proceedings than in straight bankruptcies. ${ }^{25}$ Under this view, the statutory language granting jurisdiction over the debtor's property "wherever located" merely expands territorial jurisdiction, thereby allowing the process of the court in Chapter proceedings to run beyond the district in which the court sits. ${ }^{26}$ In contrast, the Collier treatise states that the bankruptcy court in Chapter XI proceedings has "greater jurisdiction than is possessed by the court in ordinary bankruptcy proceedings under Chapters I to VII."27 Collier asserts that

21. See Section III infra.

22. See Section IV infra.

23. Comment, Summary Jurisdiction Under Chapter XI of the Bankruptcy Act: Collier v. Remington, 59 GEO. L.J. 1395 (1971) [hereinafter refcrred to as Collier v. Remington].

24. 11 U.S.C. $\$ \$ 511,711,811(1970)$.

25. 11 H. Remington, BankRuptCY $\$ 4358$ (1961 rev.) (Chapter X); 9 H. RemINGTON, BANKRUPTCY $\$ \S 3573-74$ (6th ed. 1955) '(Chapter XI).

26. $11 \mathrm{H}$. REMINGTON, BANKRUPTCY $\S 4358$ at 38 (1961 rev.).

27. 8 W. Collier, BANKRUPTCY Tा 3.01[1] (14th ed. 1976). See also Miller, The Automatic Stay in Chapter XI Cases-A Catalyst for Rehabilitation or an Abuse of Creditors' Rights?, 94 BANKING L.J. 676, 690-694 (1977) [hereinafter cited as Miller]. 
Chapter XI summary jurisdiction "rests on ownership of property, as distinguished from possession." 28

The authority of Collier on this point may be doubted, since the treatise is internally mconsistent. Earlier in the treatise, Collier concludes that when a third party holds possession of property and asserts a substantial claim to it, the Chapter X court may not summarily adjudicate rights in that property without the holder's consent. ${ }^{28}$ In Chapter $\mathrm{XI}$ proceedings, however, Collier concludes that title, rather than possession, confers summary jurisdiction. These conclusions are reached by Collier even though section 111 of Chapter $\mathrm{X}$ and section 311 of Chapter $\mathrm{XI}^{30}$ contain essentially identical language.

Certain opimions of the Court of Appeals for the Ninth Circuit support Colher's position that mere title, without possession, will support summary jurisdiction in Chapter XI proceedings. The Nimth Circuit, however, has failed to totally embrace the Collier viewpoint, ${ }^{31}$ and even its cases are, like Collier, inconsistent on this point. ${ }^{32}$ There is a similar split of authority in the Second Circuit. ${ }^{33}$

The Remington view-that actual or constructive possession is a prerequisite to summary jurisdiction in Chapter cases, as well as in straight bankruptcies-seems the sounder position. The most persuasive argument for the Collier view is that restricting jurisdiction to

28. 8 W. Collier, BankRUPtCY If 3.02 at 157 (14th ed. 1975). Collier argues that the "wherever located" language of section 311 extends summary jurisdiction to include controversies with respect to property of the debtor in the possession of a third party who does not assert a claim of ownership. Id. at 163. Collier does acknowledge the effect of section 311 in extending process beyond the territorial limits of the district in which the court is located. Id. $\$ 3.03$.

29. 6 W. CollIER, BANRRUPTCY $\ 3.05$ at 429, 436 (14th ed. 1977). With regard to Chapter X, Collier seems to agree with Remington that the language "exclusive jurisdiction of the debtor and its property wherever located" primarily affects the court's territorial jurisdiction. Id. $\mathbb{3} 3.07$ (14th ed. 1972).

30. 11 U.S.C. $\$ \$ 511$ and 711 (1970).

31. Collier v. Remington, supra note 23 , at 1405-06.

32. The followimg cases support the proposition that title alone confers summary jurisdiction on a Chapter XI court: In re Stockman Dev. Co., 447 F.2d 387 (9th Cir. 1971); Pasadena Inv. Co. v. Weaver, 376 F.2d 175 (9th Cir. 1967); Loyd v. Stewart \& Nuss, Inc., 327 F.2d 642 (9th Cir. 1964). The following cases support the proposition that possession is an essential prerequisite of summary jurisdiction in Chapter XI proceedings: Wikle v. Country Life Ins. Co., 423 F.2d 151 (9th Cir. 1970); In re Victor Builders, Inc., 418 F.2d 880 (9th Cir. 1969); Kapelus v. A Joint Venture, 377 F.2d 815 (9th Cir. 1967); In re California Paving Co., 95 F. Supp. 909 (N.D. Cal. 1951), aff'd sub. nom. California Paving Co. v. Smith, 193 F.2d 647 (9th Cir.), cert. denied, 343 U.S. 957 (1952). The following case is mconclusive on the point: In re Barasch, 439 F.2d 1393 (9th Cir. 1971). See Collier v. Remington, supra note 23, for a discussion of several of these cases.

33. Compare World Scope Publishers, Inc. v. United States, 348 F.2d 640 (2d Cir. 1965) (possession required) with Slenderella Systems of Berkeley, Inc. v. Pacific Tel. \& Tel. Co., 286 F.2d 488 (2d Cir. 1961) (possession not necessary where debtor's title is undisputed). 
cases in which there is possession hamstrings the bankruptcy court and prevents it from making orders necessary to protect debtors' estates in Chapter proceedings from disruption by foreclosures and other creditor actions. $^{34}$ However, regardless of the scope of the bankruptcy court's authority to summarily adjudicate substantive rights, the court may always mvoke its equity powers "to prevent the defeat or impairment of its jurisdiction."35 The statutory grants of jurisdiction in sections 111,311 , and $411^{36}$ are not the sole source of bankruptcy court power in Chapter proceedings-a fact often lost sight of in the dispute over summary jurisdiction. In all three Chapters X, XI, and XII, a bankruptcy court has broad power to control lien enforcement actions. ${ }^{37}$ For example, in Chapters X and XII, the court has the authority to displace non-bankruptcy receivers, trustees, and assignees for the benefit of creditors. ${ }^{38}$ Also, Chapters $\mathrm{X}$ and XII provide for the ousting of certain mortgagees and trustees in possession..$^{30}$

Therefore, a bankruptcy court, as a court of equity, may enjoin the enforcement of remedies by a secured creditor whose substantive rights it could not reach by summary adjudication. ${ }^{40}$ In Chapter XI

34. Cf. 6 W. Collier, Bankruptcy II 3.05 (1977 rev.) (Chapter X).

35. Continental Ill. Nat'l Bank v. Chicago, Rock Island \& Pac. Ry. Co., 294 U.S. 648,675 (1935).

36. 11 U.S.C. $\S \S 511,711,811$ (1970).

37. Sources of this power include the custodia legis principle under which property in the actual or constructive possession of the bankruptcy receiver, trustee, marshall, or referee, or the bankrupt or its agents, comes within the jurisdiction of the bankruptcy court, see Isaacs v. Hobbs Tie \& Timber Co., 282 U.S. 734 (1931); section 2a(15) of the Bankruptcy Act (11 U.S.C. $\$ 11(a)(15)$ (1970)), which provides that bankruptcy courts may "make such orders ... as may be necessary for the enforcement of the provisions of this act"; and the All Writs Statute, 28 U.S.C. $\$ 1651$ a (1970), which provides that federal courts "may issue all writs necessary or appropriate in aid of their respective jurisdictions and agreeable to the usages and principles of law." See Murphy, Restraint, supra note 1, at 29-30, 41-42.

38. Bankruptcy Act $\$ 2 \mathrm{a}(21), 11$ U.S.C. $\$ 11$ (a)(21) (1970); see 6 W. CollizR, BANKRUPTCY \I 3.10 (1977 rev.).

39. Bankruptcy Act $\S \S 256,257,11$ U.S.C. $\$ \S 656,657$ (1970) (Chapter X). It has been suggested that this should be extended to apply to plcdgees in possession of personal property. $6 \mathrm{~W}$. CollIER, BANKRUPTCY $\llbracket 3.05$ n.42 (1977 rev.), 6A W. Collier, BanKRUPTCY II 14.03[2] (14th ed. 1972); see Reconstruction Fin. Corp. v. Kaplan, 185 F.2d 791 (1st Cir. 1950).

Bankruptcy Act $\S \S 506,507,11$ U.S.C. $\S \S 906,907$ (1970) (Chapter XII) provides for the displacement of any receiver or trustee appointed in a prior legal proceeding and of any lienholder in possession of the debtor's real property.

40. Each of the rehabilitation chapters provides for the issuance of stays. Bankruptcy Act $\S \S 77(\mathrm{j})$ (Chapter VIII), 85(e)(4) (Chapter IX), 113, 116(4) (Chapter X), 314 (Chapter XI), and 414 (Chapter XXII), 11 U.S.C. $\S \S 205(j), 405(e)(4), 513$, $516(4), 714$, and 814 (1970 \& Supp. 1976), respectively. These have been adapted as Bankruptcy Rules 8-501, 9-4, 10-601, 11-44, and 12-43, which provide for automatic stays of legal actions against the debtor and his property.

Chapters X and XII contain automatic stays of lien enforcement in section 148 , 11 U.S.C. $\S 548$ (1970) (Chapter X) and section 428, 11 U.S.C. $\$ 828$ (1970) (Chapter 
proceedings, where a plan of arrangement cannot affect the substantive rights of a secured creditor, ${ }^{41}$ the court may nevertheless enjom a secured creditor from enforcing a lien on the debtor's property. Even if the property is in the possession of the creditor and, hence, not subject to the court's summary jurisdiction, the court may issue an injunction because "the object of the court's control is not necessarily the curtailment of rights, but the supervision of their enforcement in order to protect the interests of other creditors . . .."42 Similarly, it has been held that a Chapter XII court has the power to temporarily enjom sale of the debtor's property, in a state court mortgage foreclosure proceeding coinmenced two months prior to bankruptcy, but that the same court has no summary jurisdiction to determine legal title to the property or to enjoin the sale permanently. ${ }^{43}$ Clearly, the bankruptcy court has equitable powers distinct from its statutory powers to grant summary adjudication.

The failure to make this distinction accounts for much of the confusion on the title versus possession controversy. It is not necessary to justify the issuance of an injunction in a Chapter proceeding on the statutory ground that the court has jurisdiction of the debtor and his property, wherever located. It is "generally vital to the success of a reorganization that all the debtor's property be included, and that the continuation of the debtor's business be not unduly hampered by dissipation of the property to particular creditors, or by the separate administration of the estate in numerous forums." ${ }^{44}$ The bankruptcy court, as a court of equity, can take appropriate action to ensure that these goals are achieved so that the purpose of the Chapter proceedings is not defeated..$^{45}$ An important action by the bankruptcy court, as a court of equity, is determining whether to grant a secured creditor relief from the automatic stay in Chapter proceedings.

XII), although the latter provision applies only to "the real property or chattel real of a debtor," and Chapter IX contains a full automatic stay comparable to that of the Bankruptcy Rules in section 85(e)(1), 11 U.S.C. $\$ 405(\mathrm{e})(1)$ (1970).

41. See SEC v. American Trailer Rentals Co., 379 U.S. 594 (1965); Bankruptcy Act $\$ \S 306(1), 307,357(1), 11$ U.S.C. 706(1), 707, 757(1) (1970).

42. Lockhart v. Garden City Bank \& Trust Co., 116 F.2d 658, 660 (2d Cir. 1940); see Countryman, supra note 1, at 319-20.

43. In re Decker, 465 F.2d 294 (3d Cir. 1972). See also In re Hall Assocs., 2 Bankr. Ct. Dec. 432 (E.D. Pa. 1976) (E. Goldhaber, Bankr. Judge) in which the Chapter XII court held that a limited stay of foreclosure of a Federal Home Loan Bank did not impair the secured obligation in violation of Bankruptcy Act $\$ 517$.

44. $6 \mathrm{~W}$. Collier, BankRuptCY If 3.05 at 431 (1977 rev.).

45. See, e.g., In re Moulding-Brownell Corp., 101 F.2d 664 (7th Cir. 1939); In re Prudence Bonds Corp., 75 F.2d 262 (2d Cir. 1935). See also Festersen, Equitable Powers in Bankruptcy Rehabilitation and the Doomsday Principle, 5 CREIGHTON L. REv. 221 (1971), reprinted at 46 AM. BANKR. L.J. 311 (1972) [hereinafter cited as Festersen], in which the author's thesis is that the bankruptcy court will do whatever is necessary to prevent a secured creditor from simking a rehabilitation proceeding at the outset. 


\section{III}

\section{COMPLAINT FOR RELIEF FROM THE Automatic Stay in Chapter Proceedings}

It is virtually impossible to imagine a successful rehabilitation proceeding in which the secured creditors were not restrained from foreclosing on major assets of the debtor. Bankruptcy Act Chapters $\mathrm{X}, \mathrm{XI}$ and XII expressly contain certain automatic stays. ${ }^{46}$ Although Chapter XI provides only for a discretionary stay against lien enforceinent actions, ${ }^{47}$ common practice developed, prior to the advent of the Bankruptcy Rules, for a proposed stay order to accompany every Chapter XI petition filed. ${ }^{48}$ The Bankruptcy Rules codified this practice: Rule 11-44 states that every Chapter XI petition acts as an automatic stay of all legal actions and other proceedings ${ }^{40}$ against the debtor, and of any actions to enforce a lien agamst the debtor's property, whether commenced before or after the filing of the petition. The language of Rule 11-44 parallels that of Rules 10-601 and 12-43 which reinforce the automatic stays contained in Chapters X and XII.

For the secured creditor who wishes to collect a debt by realizing the value of the security, these automatic stays pose a number of serious problems. For example, if the court restrains a secured creditor from foreclosmg on the security, protection against depreciation of the security would be lost while in the debtor's use during the rehabilitation proceedings. ${ }^{50}$ An analysis of the procedure by which a secured creditor

46. For Chapters X and XI, Bankruptcy Act $\S \S 116(4), 314,11$ U.S.C. $\S \S 516$, 714 (1970), stays commencement or continuation of suits against the debtor. For Chapters X and XII, Bankruptcy Act $\S \S 148,428,11$ U.S.C. $\S \S 548,828$ (1970), stays enforcement of liens on the debtor's property.

47. Bankruptcy Act $\$ 314$, I1 U.S.C. \$ 714 (1970).

48. Murply, Restraint, supra note 1, at $41-42$ n.171. This practice developed despite the fact that judicial opinions invariably insisted that the granting of injunctive relief was not automatic and depended on the facts of each case; see, e.g., In re Murel Holding Corp., 75 F.2d 941 (2d Cir. 1935); In re Allied Dev. Corp., 253 F. Supp. 43 (W.D. Wisc.) rev'd sub nom. Allied Dev. Corp. v. Stephan \& Brady, Inc., 371 F.2d 325 (7th Cir. 1966).

49. The plirase "other proceedings" is directed at arbitrations. Advisory Committee's Note to Bankruptcy Rule 11-44, 2 BANKRUPTCY ACr AND RuLes 1156 (Collier Pamphlet Ed. 1976).

50. See In re Gelormmo Constr. Co., 2 Bankr. Ct. Dec. 39 (W.D. Pa. 1975) (W. Washabaugh, Jr., Bankr. Judge). The classic case on this question is In re Yale Express Sys., Inc., 370 F.2d 433 (2d Cir. 1966) and 384 F.2d 990 (2d Cir. 1967), a Chapter $X$ proceeding in which the secured creditor sought unsuccessfully to foreclose on its security or to obtam rental or use payments from the debtor. For commentary on the use of collateral by the debtor during the pendency of the bankruptcy proceeding, see Anderson, Secured Creditors: Their Rights and Remedies Under Chapter XI of the Bankruptcy Act, 81 CoM. L.J. 129 (1976) [hereinafter cited as Anderson]; Coogan, Broude \& Glatt, Comments on Some Reorganization Provisions of the Pending Bankruptcy Bills, 30 Bus. LAw. 1149 (1975); Countryman, supra note 1; Miller, supra note 
obtains relief from the automatic stays in Chapter proceedings will first examine those issues typically raised by a secured creditor's complaint for relief from the automatic stays. Second, the issues that may be raised by the debtor in response to sucl a complaint will be explored.

\section{A. Four Issues Raised By The Complaint}

Before a secured creditor can enforce a lien on the assets of a Chapter X, XI or XII debtor, relief must be obtained from the applicable automatic stay. The secured creditor must file a complaint to commence an adversary proceeding seeking to terminate, annul, modify or condition the automatic stay. ${ }^{51}$ The adversary proceeding is governed by Part VII of the Bankruptcy Rules. ${ }^{52}$ The rules provide that, after a creditor has commenced such an adversary proceeding, the debtor or other party ${ }^{53}$ seeking continuation of the stay must carry the burden of proof. ${ }^{54}$ Nevertheless, the secured creditor's complaimt must frame the issues applicable in the case and establish all essential elements of a claim for relief from an automatic stay. ${ }^{55}$ While the

27; Murphy, Use of Collateral in Business Rehabilitations: A Suggested Redrafting of Section 7-203 of the Bankruptcy Reform Act, 63 CALIF. L. Rev. 1483 (1975) [hereinafter referred to as Murphy, Use of Collateral]; Murphy, Restraint, supra note 1; Seidman, The Plight of the Secured Creditors in Chapter XI, 80 CoM. L.J. 343 (1975) [hereinafter referred to as Seidman]; Webster, Collateral Control Decisions in Chapter Cases: Clear Rules v. Judicial Discretion, 51 AM. BANKR. L.J. 197 (1977) [hereinafter cited as Webster].

51. BANKRUPTCY RULEs 10-601(c), 11-44(d), 12-43(d). In extraordinary circumstances, temporary ex parte relief is available under Rules 10-601(d), 11-44(e) and 1243(e). Procedurally, these rules correspond to Bankruptcy Rule 601, which governs relief from the stay in straight bankruptcies. See notes 10-14 supra.

52. BANKRUPTCY RULES 10-701(5), 11-61(a)(5), 12-60(a)(5).

53. See, e.g., In re Bric of America, Inc., 4 Collier Bankr. Cases 34 (M.D. Fla. 1975) (A. Paskay, Bankr. Judge) (debtor agreed to termination of the automatic stay as against a mortgagee but such relief was actively opposed by the creditors' committee).

54. Bankruptcy Rule 10-601(c) provides in part: "A party seeking continuation of a stay against lien enforcement shall show that he is entitled thereto." Rules 1144(d) and 12-43(d) contain the identical language.

See In re The Overmyer Co., 2 Bankr. Ct. Dec. 992 (S.D.N.Y. 1976) (R. Babitt, Bankr. Judge) (where the court "reluctantly" held against a Chapter XI debtor who presented no evidence, but merely speculation, as to the value of collateral); In re Jenifer Mall Corp., 2 Collier Bankr. Cases 657 (D.D.C. 1974) (R. Whelan, Bankr. Judge); Miller, supra note 27 at 705-07.

55. Rule 8 of the Federal Rules of Civil Procedure, incorporated in adversary proceedings by Bankruptcy Rule 708 and in Chapter proceedings by Bankruptcy Rules 10-701, 11-61, and 12-60, requires the creditor's complaint set forth facts sufficient to raise all essential elements of a claim for relief from the automatic stay. See In re Sal Amato, Inc., 1 Bankr. Ct. Dec. 954 (D. Conn. 1975) (S. Seidman, Bankr. Judge). See also In re Georgetown on the Delaware, Inc., 466 F.2d 80 (3d Cir. 1972), a Chapter $\mathrm{X}$ case raising similar problems with respect to a turnover order under Bankruptcy Act $\S 257,11$ U.S.C. $\S 657(1970)$. 
granting of relief from the stay is within the sound discretion of the bankruptcy court, ${ }^{56}$ courts have generally considered four issues to be relevant to an application for relief from a stay: The debtor's equity in the collateral, the likehihood of material harm to the secured creditor, the likelihood of rehabilitation, and the property's importance to the debtor's operations. ${ }^{57}$ While the prudent secured creditor is advised to raise all four issues in its complaint for relief, the court need not answer each question in the affirmative in order to continue the stay against the creditor. ${ }^{58}$

\section{Does the debtor have equity in the property that is encumbered by the security interest?}

This is the sole question to be decided on a complaint for relief from stay in straight bankruptcies, ${ }^{59}$ and it is sometimes treated as the only relevant question in Chapter proceedings. For example, when the debtor has substantial equity so that the value of the property substantially exceeds the amount of the debt, some courts have refused to grant relief from the stay ${ }^{60}$ on the theory that the creditor's position

56. In re Murel Holding Corp., 75 F.2d 941 (2d Cir. 1935); In re Tracy, 194 F. Supp. 293 (N.D. Cal. 1961).

57. In re Bric of America, Inc., Bankr. L. Rep. (CCH) I 65,651 (M.D. Fla. 1975) (A. Paskay, Bankr. Judge); In re O.K. Motels, 1 Collier Bankr. Cases 416 (M.D. Fla. 1974) (A. Paskay, Bankr. Judge); Anderson, supra note 50, at 134; Murphy, Restraint, supra note 1, at 31, 42; Seidman, supra note 50, at 346. See also In re Flying W. Airways, Inc., 442 F.2d 320, 323 (3d Cir. 1971), where it was held that substantially the same issues determine justification of a turnover order.

58. One recent article suggests at great length that there is a growing "clear rules movement" among courts to require the debtor to pass all four tests in order to obtain continuance of the stay. Webster, supra note 50, at 206-21. The authors of this Article disagree. Only the Third Circuit and Bankruptcy Judge Alexander Paskay in Florida have taken the position that relief from a stay must be granted unless the debtor can prevail on each of the four factors. As Webster's own article shows, virtually all other courts have been less demanding, believing that the court must strike an appropriatc balance among competing interests.

59. See text accompanying notes 16 through 18 supra. Since the stay serves a more limited purpose in straight bankruptcy than it does in Chapter proceedings, the issues in straight bankruptcy cases are similarly more limited. It has been suggested that the factors to be considered will be different in Chapter XI, where a secured creditor's rights cannot be modified, than in Chapters X and XII, where alteration of a secured creditor's rights is allowed. See, e.g., Murphy, Restraint, supra note 1, at 42. The primary purpose of the stay, however, in Chapter proceedings is to aid the debtor in his rehabilitation efforts, and this purpose is the same regardless of the Chapter involved. See text accompanying notes 40-45 supra. The factors to be considered regarding relief from the stay should also be the same in all three business rehabilitation chapters.

60. In re U.S. Realty \& Improvement Co., 153 F.2d 853 (2d Cir. 1946) (Chapter $X$ ); In re Blazon Flexible Flyer, Inc., 407 F. Supp. 861 (N.D. Ohio 1976) (Chapter $\mathrm{XI}$ ); In re Atlantic Steel Prods. Corp., 31 F. Supp. 408 (E.D.N.Y. 1939) (Chapter $\mathrm{XI})$. 
is secure. Similarly, when the value of the security is less than the amount of the debt, some courts ${ }^{61}$ have vacated the stay, the absence of equity rendering the other issues moot. ${ }^{62}$ The idea of equity, then, has become something of a totem for the courts.

Deciding whether to continue or vacate a stay solely on the ground of the debtor's equity in the property may produce an unjust result. For example, situations arise in which the amount of the secured debt exceeds the value of the collateral but the encumbered property is so vital to the operation of the debtor's business that foreclosure will simply not be allowed. ${ }^{63}$ The court should examine several factors, including whether the encumbered property is the only property of the debtor, whether it is indispensable to the debtor's business, ${ }^{64}$ and what the debtor's chances are for effectuating a plan of rehabilitation. ${ }^{65}$ The following hypothetical situation should illustrate: A land developer finances construction of an apartment complex by means of a $\$ 500,000$ bank loan secured by the real estate. The bank's appraisal shows the undeveloped property to be worth $\$ 1,000,000$. The developer, however, imcurs cost overruns and construction delays which render it impossible to complete the project for occupancy before the loan is in default. The developer files a petition under Chapter XI. Meanwhile, the state and federal governments pass environmental protection legislation that makes construction more costly, and the developer's permit from the county government approaches expiration at a time when local opposition is mobilized against the project. When the bank seeks relief from the Rule 11-44 stay, it prepares a new appraisal which shows that the value of the property now equals the amount of secured debt. What does the court do? On the one hand, the court may find that, due to the described circumstances, the developer no longer has any equity in the real estate and that the project is accruing

61. Caplan v. Anderson, 256 F.2d 416 (5th Cir. 1958) (Chapter X); In re Third Ave. Transit Corp., 198 F.2d 703 (2d Cir. 1952) (Chapter X).

62. In re DLB Dev. Corp., 1 Bankr. Ct. Dec. 1463 (S.D. Cal. 1975) (K. McWilliams, Bankr. Judge). One court has suggested that it was required to protect a secured creditor where the debtor's alleged equity in the security was not sufficiently. large. In In re Georgetown on the Delaware, Inc., 466 F.2d 80 (3d Cir. 1972), the Chapter $X$ trustee asserted the debtor's "book value equity" in certain realty was $\$ 19,974.50$. However, the court did not find this "meaningful" in relation to the value of the debtor's total assets, alleged to be $\$ 3,313,513.00$, and current and long tern liabilities of $\$ 3,519$,859.00. Id. at 82-83.

63. See, e.g., In re American Kitchen Foods, Inc., 2 Bankr. Ct. Dec. 715 (D. Me. 1976) (C. Cyr, Bankr. Judge). The remedy fashioned by the court in this case is discussed at text accompanying notes 101-102 infra.

64. In $r e$ IFC International, [1977 Transfer Binder] BANKR. L. REP. (CCH) If 66,380 (M.D.Fla. 1977) (A. Paskay, Bankr. Judge).

65. In re ABC Dev. \& Inv. Co., Inc., $[1977$ Transfer Binder] BANKR. L. REP. (CCH) $\pi 66,382$ (M.D.Fla. 1977) (A. Paskay, Bankr. Judge). 
unpaid taxes and interest. On the other hand, given time, the developer may be able to salvage the project and produce substantial equity for itself and the general creditors.

The court cannot solve this problem by clinging to the totem, "equity." The court must also consider whether the property's value may continue to depreciate (resultimg in a loss to the secured creditor), whether the debtor has reasonable prospects for rehabilitation, and whether the property is vital to the conduct of the debtor's business. ${ }^{\circ 0}$ One commentator has even suggested that these three factors should be considered by the court before the equity issue is addressed, on the theory that equity becomes an issue only if withdrawal of the property from the debtor will affect the prospects of an arrangement or reorganization that has a reasonable chance of succeeding. ${ }^{.7}$

Valuing the property to determine if an equity exists must be distimguished from the evaluation required to determine if the debtor has reasonable chances of rehabilitation. It has been noted that debtors frequently exhibit considerable enthusiasm and optimism over proposed plans for the property, ${ }^{88}$ which, if carried to fruition, would result in property value above the amount of secured debt. The property, however, should be valued as of the date of filing the complaint for relief from stay, ${ }^{09}$ and this determination is distinct from the possibly higher value which might be achieved if a successful plan is later implemented.

In determining the debtor's equity, the court should include all items of imdebtedness. If provision is made in the security agreement, the secured creditor is entitled to attorneys' fees ${ }^{70}$ and post-petition interest where the collateral is sufficient to pay the full debt. ${ }^{71}$ The bankruptcy court should therefore consider the amount of attorneys' fees and accrued interest in determining whether there exists equity in the property for the purposes of a complaint for relief from stay. ${ }^{72}$

2. Will continuation of the stay cause undue harm to the secured creditor?

This question is so closely related to the question of equity that

66. In re Empire Steel Co., 228 F. Supp. 316 (D. Utah 1964); In re Tracy, 194 F. Supp. 293 (N.D. Cal. 1961).

67. Seidman, supra note 50, at 347 .

68. See, e.g., In re DLB Dev. Corp., 1 Bankr. Ct. Dec. 1463 (S.D. Cal. 1975) (K. McWilliams, Bankr. Judge).

69. See text accompanying notes 144-149 infra. The court should account for any erosion in the value of collateral that may have occurred since the filing of the petition. Cf. Murphy, Use of Collateral, supra note 50, at 1510.

70. Security Mortgage Co. v. Powers, 278 U.S. 84 (1928).

71. United States v. Sampsell, 153 F.2d 731 (9th Cir. 1946).

72. See, e.g., In re DLB Dev. Corp., 1 Bankr. Ct. Dec. 1463 (S.D. Cal. 1975) 
the two are often collapsed into one. Courts often assume that where there is excess collateral for a secured debt, the creditor cannot be heard to complain of a stay of foreclosure; and, on the contrary, that where the secured debt exceeds the value of the collateral, the secured creditor will always suffer from a stay. ${ }^{73}$ Neither assumption is always justified. Even where there is substantial property value in excess of secured debt, the creditor suffers harm as long as unpaid real property taxes accrue in the property, ${ }^{74}$ thereby dissipating the equity cushion. ${ }^{75}$ Moreover, the secured creditor is deprived of the use of money, ${ }^{76}$ and this may, in turn, result in impairment of the creditor's own standing with fimancial institutions. ${ }^{7 \pi}$ On the other hand, a secured creditor whose debt far exceeds the collateral may not suffer from a stay if such collateral does not depreciate while in use by the debtor during Chapter proceedings. Indeed, an undersecured creditor might benefit from a stay which enables the debtor to continue to use the collateral. Suppose that at the time a debtor files a petition under Chapter XI, the collateral of a secured creditor consists mainly of raw materials and work in progress with negligible hiquidation value. The creditor is not harmed if, during the Chapter XI proceedings, the collateral is turned into finished inventory. ${ }^{78}$

Nevertheless, it has sometimes been suggested that where a rehabilitation court cannot assure that the secured creditor will not suffer loss as a result of a stay in the Chapter proceedings, foreclosure should be allowed. ${ }^{79}$ This is too stark a formulation of the appropriate test. ${ }^{80}$

(K. McWilliams, Bankr. Judge) where the court included $\$ 34,984.50$ in attorney's fees in the amount of the debt without passing upon their reasonableness.

73. See Caplan v. Anderson, 256 F.2d 416 (5th Cir. 1958) (Chapter X); In re Third Ave. Transit Corp., 198 F.2d 703 (2d Cir. 1952) (Chapter X); In re U.S. Realty \& Improveinent Co., 153 F.2d 853 (2d Cir. 1946) (Chapter X); In re Blazon Flexible Flyer, Inc., 407 F. Supp. 861 (N.D. Ohio 1976) (Chapter XI); In re Atlantic Steel Prods. Corp., 31 F. Supp. 408 (E.D.N.Y. 1939) (Chapter XI).

74. In re Sixth Ave. Inv. \& Dev. Co., 2 Bankr. Ct. Dec. 1222 (S.D. Cal. 1976) (R. Pyle, Bankr. Judge).

75. "Equity cushion" refers to the amount by which the value of the security exceeds the amount of the debt.

76. In re Sixth Ave. Inv. \& Dev. Co., 2 Bankr. Ct. Dec. 1222 (S.D. Cal. 1976) (R. Pyle, Bankr. Judge).

77. See In re DLB Dev. Corp., 1 Bankr. Ct. Dec. 1463 (S.D. Cal. 1975) (K. McWilliams, Bankr. Judge) (secured creditor forced to borrow funds at a higher interest rate than that required on its loan to debtor).

78. Cf. Reconstruction Fin. Corp. v. Kaplan, 185 F.2d 791 (1st Cir. 1950) (permitting debtor to assemble inventory to finished goods and to complete work in progress strengthened net position of secured creditor).

79. See, e.g., Caplan v. Anderson, 256 F.2d 416 (5th Cir. 1958).

80. Compare In re Third Ave. Transit Corp., 198 F.2d 703 (2d Cir. 1952) and In re Penn Cent. Transp. Co., 494 F.2d 270 (3d Cir.), cert. denied, 419 U.S. 883 (1974) (to justify a turnover order in Chapter $X$, the trustee must show a high degree of likeli- 
The court must, of course, consider the rights of the secured creditor, ${ }^{81}$ and it cannot employ a stay of foreclosure in such a way as to modify those rights. ${ }^{82}$ The rehabilitation court, however, also must.protect the rights of the debtor and of the general creditors.

The court should, therefore, balance the relative harm to partiesthe burden that the secured creditor may suffer as a result of a stay, as against the hardship that the debtor and general creditors may suffer as a result of foreclosure. This balancing test, traditionally used by equity courts in ruling on requests for injunctive relief, ${ }^{83}$ is appropriate for evaluating continuation of the automatic stay because the stay is in the nature of a temporary injunction designed to maintain the status quo. ${ }^{84}$

One recent case, In re Groundhog Mountain Corp. ${ }^{85}$ illustrates this balancing approach. There, the debtor's sole asset was encumbered real estate that a secured creditor sought to foreclose. By granting relief from the automatic stay in these circumstances, the bankruptcy court was effectively putting the debtor out of business. But the court determined that the "balance of hurt" fell on the side of the secured creditor, who had not received payments of principal and interest or deposits of taxes from the debtor. In reaching his conclusion on the balance of hurt, the judge heavily weighed the debtor's prospects for rehabilitation, ${ }^{86}$ a factor that is considered next.

\section{Is there a reasonable possibility of successful rehabilitation?}

The likelihood of rehabilitation has long been an issue in the stay

hood of reorganization within a reasonable time and that the secured creditors will not be injured) with In re Chicago, Rock Island \& Pac. R.R. Co., 545 F.2d 1087 (7th Cir. 1976) which finds the Third Avenue test too stringent and resists elevating it to constitutional status.

81. At soine point, continuation of the automatic stay may cross the line between mere postponement of a secured creditor's remedies and erosion of security which amounts to a taking in violation of the fifth amendment. In re Empire Steel Co., 228 F. Supp. 316, 319 (D. Utah 1964) ("[t]he 'status' of secured creditors then unavoidably would be affected [by prolonged continuation of a stay], for status depends not only upon assurance of eventual payment but the right to payment or enforcement in point of time bearing some relation to the conditions of the security instruments"). But compare In re Chicago, Rock Island \& Pac. R.R. Co., 545 F.2d 1087, 1090 (7th Cir. 1976) ("It]he due process clause of the [Fifth] Amendment is not violated by anything less than actual impairnent of a creditor's security") with In re Penn Cent. Transp. Co. (Columbus Option), 494 F.2d 270 (3d Cir.), cert. denied, 419 U.S. 883 (1974) (requiring a high degree of likelihood of reorganization within a reasonable time).

82. Chaffee County Fluorspar Corp. v. Athan, 169 F.2d 448 (10th Cir. 1948); In re Empire Steel Co., 228 F. Supp. 316, 319 (D. Utah 1964).

83. 11 C. Wright \& A. Miller, Federal Practice and Procedure \& 2948, at 442-49 (1973).

84. In re Decker, 465 F.2d 294, 297 (3d Cir. 1972).

85. 1 Bankr. Ct. Dec. 923 (S.D.N.Y. 1975) (R. Babitt, Bankr. Judge).

86. Id. at 925-26. 
provisions of Chapter $X .^{87}$ Recent authority supports consideration of this issue in Chapter $\mathrm{XI}^{88}$ and Chapter $\mathrm{X \Pi}^{89}$ proceedings as well. Perhaps the courts should first consider the debtor's prospects for rehabilitation. If the prospects are dim, the court could logically refuse to proceed within the rehabilitation framework on the ground that its jurisdiction had been improperly invoked. ${ }^{90}$ But even in Chapter X cases where the original petition must be filed in "good faith" and is subject to immediate dismissal if "it is unreasonable to expect that a plan of reorganization can be effected," ${ }^{\prime 1}$ courts are reluctant to conclude at the outset that the proceedings are doomed to fail. The courts will usually give the debtor a reasonable time to work out an eligible rehabilitative plan before they determine that the proceedings are not likely to succeed. ${ }^{92}$ Indeed, the lapse of time without progress seems to be the principal test for determining that a plan is not feasible, although, on occasion, a court does reject a proposed plan on its inerits. ${ }^{93}$

Although the equity position of the debtor and the possibility of harm to the secured creditor are often the determinative factors in coinplaints for rehef from the stay, a poor likelihood for rehabilitation alone

87. Lincoln-Alliance Bank \& Trust Co. v. Dye, 115 F.2d 234 (2d Cir. 1940); In re Murel Holding Corp., 75 F.2d 941 (2d Cir. 1935).

88. See, e.g., In re Empire Steel Co., 228 F. Supp. 316 (D. Utah, 1964); In re IFC International, [1977 Transfer Binder] BANKR. L. REP. (CCH) I 66,380 (M.D.Fla. 1977) (A. Paskay, Bankr. Judge); In re ABC Dev. Inv. Co., Inc., [1977 Transfer Binder] Bank. L. ReP. (CCH) $\pi 66,382$ (M.D. Fla. 1977) (A. Paskay, Bankr. Judge); In re Sal Amato, Inc., 1 Bankr. Ct. Dec. 954 (D. Conn. 1975) (S. Seidman, Bankr. Judge); In re Groundhog Mountain Corp., 1 Bankr. Ct. Dec. 923 (S.D.N.Y. 1975) (R. Babitt, Bankr. Judge).

89. In re Pine Gate Assocs., Ltd., 3 Bankr. Ct. Dec. 141 (N.D. Ga. 1976) (W. Norton, Jr., Bankr. Judge); In re Triangle Inn Assocs., 2 Bankr. Ct. Dec. 1670 (E.D. Va. 1976) (H. Bonney, Jr., Bankr. Judge). See also In re Pembroke Manor Apts., 547 F.2d 805 (4th Cir. 1977).

90. "[I] know of no rule of law which denies to this Court consideration of whether or not it has been imposed on by the filing of this Chapter XI petition on all the facts here as a relevant factor to consider in determining to continue a stay." In re Groundhog Mountain Corp., 1 Bankr. Ct. Dec. 923, 925 (S.D.N.Y. 1975) (R. Babitt, Bankr. Judge).

91. Bankruptcy Act $\$ 146(3), 11$ U.S.C. $\$ 546$ (1970).

92. The following cases illustrate the range of time that may elapse between the debtor's filing of a petition and the bankruptcy court's order allowing relief from the stay: Lance, Inc. v. Devco Serv., Inc., 422 F.2d 778 (9th Cir. 1970) (five months); In re Holiday Lodge, Inc., 300 F.2d 516 (7th Cir. 1962) (thirteen months); LincolnAlliance Bauk \& Trust Co. v. Dye, 115 F.2d 234 (2d Cir. 1940) (fourteen months); In re Hartsdale Assocs., 2 Bankr. Ct. Dec. 1275 (S.D.N.Y. 1976) (H. Schwartzberg, Bankr. Judge) (eight months); In re Groundhog Mountain Corp., 1 Bankr. Ct. Dec. 923 (S.D.N.Y. 1975) (R. Babitt, Bankr. Judge) (eleven months).

93. See, e.g., In re Murel Holding Corp., 75 F.2d 941 (2d Cir. 1935), in which Judge Learned Hand determined that a plan of corporate reorganization was not feasible where it required the holder of a first mortgage to forego all amortization payments for a period of ten years. See also Lance Inc. v. Devco Serv. Inc., 422 F.2d 778 (9th Cir. 1970) (proposed Chapter XI plan not feasible). 
may justify relief. In In re Empire Steel Co. ${ }^{94}$ a Chapter XI proceeding had been pending for over a year without progress toward a plan when the stay against the principal secured creditor reached the district court on appeal. Despite strong evidence that the debtor had substantial equity in the encumbered property, the district court determined that the stay should be vacated because the debtor had no real prospects for rehabilitation. Whatever the equity position of the debtor may be, no justifiable basis exists for denying a secured creditor the right to foreclose when the debtor cannot demonstrate that rehabilitation is possible. ${ }^{95}$

The requirement of a reasonable possibility for rehabilitation should be evaluated in terns of an eligible plan under the Bankruptcy Act, and the requirement is not satisfied by a mere business plan that does not otherwise qualify under the applicable chapter of the Act. For example, a Chapter XII arrangement must include provisions that alter or modify the rights of secured creditors. ${ }^{90} \mathrm{~A}$ proposed plan that does not mclude such provisions should not satisfy the requirement of a possibility of rehabilitation for continuation of the automatic stay in a Chapter XII proceeding.

\section{Will withdrawal of the encumbered property materially affect the prospects of rehabilitation?}

One commentator has suggested that a bankruptcy court in rehabilitation proceedings will do anything to a secured creditor that is necessary to promote the end of rehabilitation, and that if there is any way to help a debtor hold on to property, the courts will find it. ${ }^{27}$ The courts, however, are not nearly so indiscriminate. Courts have often relieved secured creditors of the burden of a stay where it appeared that the encumbered property was not essential in rehabilitation

94. 228 F. Supp. 316 (D. Utah 1964).

95. If there is no possibility of submitting a plan except upon the happening of some future contingency, the basis for any protracted stay simply does not exist. Otherwise, secured creditors could be indefinitely delayed, for almost every debtor hopes that something may happen in the future to relieve his Id. at 319. plight and permit him to avoid foreclosure.

96. Bankruptcy Act $\$ 461(1), 11$ U.S.C. $\S 861$ (1970).

97. See Festersen, supra note 45. Addressing a related problem, treatment of bankruptcy termination clauses in leases, one court invoked the "public interest" to justify restraint of eviction proceedings by a lessor of liquor store premises. Queens Boulevard Wine \& Liquor Corp. v. Blum, 503 F.2d 202 (2d Cir. 1974). The authority of that case is weakened by the same court's subsequent opinion in In re D.H. Overmyer Co., 510 F.2d 329 (2d Cir. 1975) (distinguishing Queens Boulevard and holding that the district court did not abuse its discretion by terminating the leases where the debtor had a pattern of poor relationships with the landlords and where there was no prospect for future improvement). 
of the debtor's business. In In re Tracy, ${ }^{98}$ a Chapter XI proceeding, the debtor owned two pieces of real property, a home and a place of business. The court enjoined foreclosure on the debtor's place of business. Despite evidence that the debtor had substantial equity in the residential property, the district court reversed the bankruptcy court's stay of foreclosure on the debtor's home because the residence was not of "essential necessity" in the operation of the debtor's business. ${ }^{99}$

Courts are not limited to simply considering the four factors discussed above, and then either continuing the stay or permitting foreclosure. Consider the following situation: The debtor has little or no equity in the security, and the secured creditor's position is threatened by a continuation of the stay. The collateral, however, is important to the debtor's business, which nay have a chance of recovering if the collateral may be used. In this situation, vacating the stay and allowing foreclosure will defeat the rehabilitative purposes of the Chapter proceeding. Continuing the stay may significantly harm the secured creditor, possibly in violation of fifth amendenent rights. ${ }^{100}$ When this dilemma arises, a compromise solution is both appropriate and proper.

In In re American Kitchen Foods, Inc., ${ }^{101}$ the bankruptcy court permitted a Chapter XI debtor to continue to use all of the encumbered personal property assets, mcluding machinery and proceeds of accounts and inventory, over the strenuous objection of secured creditors. The court stressed the debtor's importance to the local economy and its employment of a large portion of the populace. However, the court order also provided the secured creditors with an administrative claim for any loss suffered as a result of the use and depreciation in value of the collateral during the pendency of the proceeding, as well as granting them a first priority lien on all the debtor's assets to secure that administrative claim. In smilar situations in which secured creditors seek rehef from the automatic stay, a bankruptcy court should forbid foreclosure if it can fashion an order that would protect the secured creditor from suffering increased loss during the Chapter proceedings. ${ }^{102}$

98. 194 F. Supp. 293 (N.D. Cal. 1961).

99. Id. at 296. See In re IFC International, [1977 Transfer Binder] BANKR. L. ReP. (CCH) If 66,380 (M.D. Fla. 1977) (A. Paskay, Bankr. Judge) (encumbered property held not indispensable to rehabilitation even though equity in property would be helpful to debtor).

100. See notes 1 and 81 supra.

101. 2 Bankr. Ct. Dec. 715 (D. Me. 1976) (C. Cyr, Bankr. Judge).

102. See Festersen, supra note 45. 


\section{B. Determining the Debtor's Equity}

\section{Admissibility of Evidence}

In addressing the issues of the debtor's equity in property, or the amount of the secured debt, the court's task is essentially one of fact finding. To determine the debtor's equity in the property, the court must ascertain the value of the property, the amount of encumbrances on the property, and the difference between the value and the encumbrances. ${ }^{103}$ What is the proper evidentiary standard in a hearing on complaint for relief from the stay? By their terms, the Federal Rules of Evidence apply to proceedings and cases under the Bankruptcy Act, ${ }^{104}$ including matters heard by the bankruptcy judge, ${ }^{105}$ and inatters heard by the district court sitting as a court of bankruptcy.

Despite the apparent applicability of the Federal Rules, use of the more relaxed standard that governs admissibility of evidence in preliminary injunction hearings would be consistent with the view presented here that a hearing on relief froin the automatic stay is analogous to a hearing on a preliminary injunction. At least two reasons for permitting otherwise inadmissible evidence in preliminary injunction hearings ${ }^{\mathbf{1 0 6}}$ would apply in a hearing on a complaint for relief from stay: The hearing does not adjudicate the merits of a substantive controversy, ${ }^{107}$ and the court, in making a discretionary judgment based on its evaluation of the relative equities, ${ }^{108}$ ought to be allowed to give otherwise inadmissible evidence some weight. Inadmissibility under the rules should affect the weight and credibility of evidence, but should not be a bar to the introduction of evidence in a hearing on a complaint for relief from the automatic stay. ${ }^{109}$

Other considerations support the use of a relaxed evidentiary standard. Ascertaining the ainount of debt encumbering property can be a problem for some institutional lenders which use complicated data processing techniques to account for receipts and disbursements and

103. In re DLB Dev. Corp., 1 Bankr. Ct. Dec. 1463, 1467 (S.D. Cal. 1975) (K. McWilliams, Bankr. Judge).

104. FED. R. EvD. 1101(b).

105. FED. R. Evid. 1101(a).

106. C. Wright \& A. Miller, Federal Practice aNd Procedure $\$ 2949$, at 471 73 (1973).

107. See text accompanying note 84 supra.

108. See note 56 supra.

109. But see In re Victor Builders, Inc., 418 F.2d 880, 882 (9th Cir. 1969), a decision that preceded the automatic stay provisions of Bankruptcy Rules, where the court distinguished between "cause shown" in support of a temporary stay against lien enforcement and "cause shown" required for the issuance of a "permanent" restraint of lien enforcement until final decree under Bankruptcy Act $\S 314$. The court held that the latter "must be supported by evidence." 
to allocate payinents to principal and interest. If the Federal Rules of Evidence were to govern admissibility in a hearing on relief from the stay, introducing this data would require the secured creditor to either satisfy the business records exception to the hearsay rule ${ }^{110}$ or alternatively to rely on the catchall hearsay exception. ${ }^{111}$ The secured creditor should be allowed to inake some prelininary showing with regard to the amount of debt, regardless of whether the material presented would otherwise be considered hearsay. ${ }^{112}$

Ascertaining the value of the property creates questions concerning the standard of admissibility of evidence. Soine bankruptcy courts will consider any reasonable presentation of evidence in arriving at a valuation figure. ${ }^{113}$ In contrast, at least one bankruptcy court ${ }^{114}$ has strictly limited the type of testimony that it would consider in real property valuation, even to the extent of refusing to accept the testimony of one $\mathrm{MAI}^{115}$ appraiser because his appraisal was conducted before the electoral defeat of a local land use planning ineasure. ${ }^{116}$ The court held that it was bound by the generally recognized approaches to determining inarket value that are found in federal condeinnation cases. ${ }^{117}$

The federal condemnation cases are helpful for situations involving real property since they use valuation evidence based on the three

110. FED. R. Evid. 803(6). Computerized records pose particular problems of admissibility as business records. See, e.g., United States v. DeGeorgia, 420 F.2d 889 (9th Cir. 1969).

111. FED. R. Evid. 803(24).

112. Proving the amount of the debt has most often been raised in cases in which the debtor has argued that the debt is subject to offsets and counterclaims. See text accompanying notes 153-215 infra.

113. In re Sixth Ave. Inv. \& Dev. Co., 2 Bankr. Ct. Dec. 1222 (S.D. Cal. 1976) (R. Pyle, Bankr. Judge). The court heard presentations by two MAI appraisers, see note 115 infra, as well as testimony by two partners of the debtor; accord, In re The Overmyer Co., 2 Bankr. Ct. Dec. 992 (S.D.N.Y. 1976) (R. Babitt, Bankr. Judge) holding the debtor must present at least some evidence, beyond bare allegations, of the value of pledged corporate stock.

114. In re DLB Dev. Corp., 1 Bankr. Ct. Dec. 1463 (S.D. Cal. 1975) (K. McWilliams, Bankr. Judge).

115. The abbreviation "MAI" refers to a Member of the American Institute of Real Estate Appraisers, which imposes uniform standards for the appraisal of real property. The Institute recognizes three methods of appraisal: reproduction cost, comparable sales, and income approach. An MAI is directed to apply the method that is most reliable for a particular piece of real property. See AMERICAN INSTITUTE of REAL EsTATE ApPraisers, The APPraisal of ReAl Estate 64-71 (6th ed. 1974).

116. In re DLB Dev. Corp., 1 Bankr. Ct. Dec. 1463 (S.D. Cal. 1975) (K. McWilliams, Bankr. Judge). The court accorded little weight to the testimony of debtor's corporate officer and to the debtor's other appraiser who failed to conduct a thorough, independent study, and held that the debtor failed to establish by a preponderance of evidence the fair value of the property. Id. at 1467.

117. Id., citing United States v. 100 Acres of Land, 468 F.2d 1261 (9th Cir. 1972). 
MAI-approved techniques, ${ }^{118}$ while naaintaining flexibility to consider less conventional valuation techniques where special circumstances indicate that other methods may have probative value. ${ }^{110}$ In practice, when a bankruptcy court is presented with conflicting appraisal testimony there is a tendency to "average" the figures to arrive at appraised value. ${ }^{120}$

In determining the type of evidence to admit on the valuation question, one factor which niay not be fully appreciated by the courts is the substantial cost of preparing a full, independent MAI appraisal for purposes of litigating a coniplaint for relief from stay. ${ }^{121}$ The courts should consider the short cash position of the typical chapter debtor, ${ }^{122}$ as well as the limited resources of a non-institutional secured lender such as a purchase nioney vendor.

\section{Valuation Standard}

In addition to determining what evidence it will consider, a court hearing a coniplaint for relief from the automatic stay nust also determine what standard it will apply to ascertain the value of encunibered property. While most bankruptcy court hearings on relief from the stay assunie the standard to be applied is that of fair market value, ${ }^{123}$

118. See United States v. 100 Acres of Land, 468 F.2d 1261, 1265 (9th Cir. 1972), approving the three approaches of comparable sales, income or capitalization, and reproduction cost.

119. Id. Evidence based on the "developer's residual" approach was held to be admissible, although feasibility of development was a questiou of probability for the trier of fact. See also United States v. 25.02 Acres of Land, 495 F.2d 1398 (10th Cir. 1974) (consideration of special circunstances may have probative value).

Compare the limited admissibility rules operative in California eminent domain and inverse condemnation cases, which are governed by a strict statutory scheme. CAL. Evid. CODE $\S \S 810-22$ (West 1966 \& Supp. 1977). For example, use of the capitalization method is restricted, CAL. Evid. CoDE $\$ 819$ (West 1966), and would continue to be limited, although to a lesser degree, under a revised statute recommended by the California Law Revision Commission. See New Evidence Rule on Property Value Aired, The Los Angeles Daily Journal, April 13, 1977, at 1, col. 3.

120. See, e.g., In re Sixth Ave. Inv. \& Dev. Co., 2 Bankr. Ct. Dec. 1222 (S.D. Cal. 1976) (R. Pyle, Bankr. Judge).

121. Cf. In re Pine Gate Assocs., Ltd., 3 Bankr. Ct. Dec. 301 (N.D. Ga. 1977) (W. Norton, Bankr. Judge) where the parties prepared appraisal testimony for a complaint for relief froin stay hearing and used the same evidence in a $\$ 461$ (11) cramdown hearing six months later. The bankruptcy court complained that the quality of evidence was not responsive to the court's requirements for valuation for purposes of a cramdown.

122. See In re DLB Dev. Corp., 1 Bankr. Ct. Dec. 1463 (S.D. Cal. 1975) (K. McWilliams, Bankr. Judge) where the debtor was unable to present an expert independent appraisal of current market value. Frequently, instead of a full report, the debtor resorts to a letter of appraisal, in which the appraiser is unwilling to certify his opinion of market value. Alternatively, the debtor may merely commission an expert to review and criticize the certified appraisal presented by the creditor.

123. See, e.g., In re Sixth Ave. Inv. \& Dev. Co., 2 Bankr. Ct. Dec. 1222 (S.D. Cal. 1976) (R. Pyle, Bankr. Judge); In re The Overmyer Co., 2 Bankr. Ct. Dec. 992 (S.D.N.Y. 1976) (R. Babitt, Bankr. Judge). 
the court could look instead to the liquidation value of the collateral. Since the significant difference between an unsecured and a secured creditor is the latter's ability to realize on certain property inade specifically available for payment of its debt, ${ }^{124}$ it can be argued that liquidation value (the value that can be realized at a forced sale) is most appropriate in determining whether the secured creditor should be granted relief from the automatic stay. At least one court has used a forced sale standard in determining whether a secured creditor would suffer harm by continuation of a stay against foreclosure. ${ }^{125}$ In an analogous situation, where a debtor has obtained a state court injunction against foreclosure, the injunction bond is imtended to coinpensate the secured creditor for all dainages proximately caused by the injunction. The amount of the bond is calculated on the basis of what price can be obtained for the property at a forced sale. ${ }^{126}$ A forced sale price is usually less than what might be obtained at a negotiated sale between a willing seller and a willing buyer. ${ }^{127}$ On the other hand, while forced sale valuation is consistent with the inimimum to which a secured creditor is constitutionally entitled, ${ }^{128}$ it is by no means certain that the secured creditor's constitutional right is limited to liquidation value. ${ }^{128}$ Moreover, the Fourth Circuit has recently overturned a district court decision that vacated a stay against foreclosure based on the liquidation value of collateral. ${ }^{130}$

Alternatively, debtors have requested courts to value the property according to soine special use it may hold for the debtor. Generally, courts have rejected this "special benefit" test for valuation purposes. ${ }^{131}$

124. In re Empire Steel Co., 228 F. Supp. 316, 319 (D. Utah 1964).

125. In re Stevens Enterprises, Inc., 148 F. Supp. 12, 14 (E.D. Pa. 1957).

126. Yellen v. Fidelity \& Cas. Co. of New York, 115 Cal. App. 434, 1 P.2d 1019 (1931) (secured creditor entitled to damages equal to the difference between what could be expected to be recovered at the forced sale which was enjoined and what was actually received from forced sale at a later date); Surety Sav. \& Loan Ass'n v. National Automobile \& Casualty Ins. Co., 8 Cal. App. 3d 752, 87 Cal. Rptr. 572 (1970) (recovery on injunction bond may include amount equal to interest on proceeds actually obtained at forced sale).

127. Yellen v. Fidelity \& Cas. Co., 115 Cal. App. 434, 441, 1 P.2d 1019, 1022 (1931); see In re Stevens Enterprises, Inc., 148 F. Supp. 12, 14 (E.D. Pa. 1957).

128. Wright v. Union Cent. Life Ins. Co., 311 U.S. 273, 278 (1940); Louisville Joint Stock Land Bank v. Radford, 295 U.S. 555 (1935).

129. Cf. Sexton v. Dreyfus, 219 U.S. 339 (1911) (secured creditor entitled to interest accrued on pledged securities during pendency of proceedings).

130. Reliance Standard Life Ins. Co. v. Pembroke Manor Apts., [1977 Transfer Binder] BANKR. L. REP. (CCH) \ 66,321 (4th Cir. 1977). The bankruptcy court heard the question of confirmation of a plan and a complaint for relief from stay at the same tine. Liquidation value is a necessary test to determine if a creditor is partially unsecured for confirnation purposes pursuant to Bankruptcy Act $\S 453$. On review froin the bankruptcy court, the district court vacated the stay based on liquidation value evidence. This decision was reversed by the court of appeals.

131. See, e.g., In re The Overnnyer Co., 2 Bankr. Ct. Dec. 992 (S.D.N.Y. 1976) 
Adoption of a special benefit test would penalize those secured creditors whose debtors were sufficiently imaginative (and persuasive) to convince the court of the likelihood of their profitmaking designs, and would tend to blur the important distinction between the debtor's current equity in the property and the debtor's chances of rehabilitation in the future. ${ }^{132}$

Most relief from stay cases that involve real property apply a fair inarket value standard. ${ }^{133}$ Certainly inarket value is a reasonable coinpromise between a test of forced sale valuation (which may work harsh results on debtors by appearing to minimize their equity) and a special benefit test (which would operate to the disadvantage of secured creditors). The federal condeinnation cases adopt fair market value as a "practical standard" designed to put the owner "in as good position pecuniarily as he would have occupied if his property had not been taken."134 These cases provide ample precedent to guide the bankruptcy courts in the application of a market value standard. ${ }^{135}$

Few cases have considered the problein of valuing personal property collateral for purposes of a coinplaint for relief from stay. ${ }^{138}$ In valuing personal property, the terms "liquidation" value or "fair nnarket" value are inherently imprecise: Collateral nay be "liquidated" by sale in a gradual and orderly manner or liquidation may connote foreclosure and direct notification of account debtors. ${ }^{137}$ Upon a debtor's default, the secured creditor is ordinarily obligated to dispose of collateral in a commercially reasonable inanner. ${ }^{138}$ This standard, however, begs the question since coinmercial reasonableness must be determined in light of the particular circuinstances.

(R. Babitt, Bankr. Judge) (court rejected bare allegation that pledged stock has value "far in excess" of appraised value); In re DLB Dev. Corp., 1 Bankr. Ct. Dec. 1463 (S.D. Cal. 1975) (K. McWilliams, Bankr. Judge) (court rejected debtor's estimation of value based on development of property where land cannot be developed for a substantial period of time).

132. See text accompanying notes 68-69 supra. Cf. In re Triangle Inn Assocs., 2 Bankr. Ct. Dec. 1670 (E.D. Va. 1976) (H. Bonney, Bankr. Judge) (where the debtor was ordered to submit a plan based on its current business situation rather than hold its creditors at bay waiting for a seasonal upturn in the economy).

133. See, e.g., In re Capri Dev. Co., 2 Bankr. Ct. Dec. 1294 (S.D. Cal. 1976) (H. Katz, Bankr. Judge); In re Sixth Ave. Inv. \& Dev. Co., 2 Bankr. Ct. Dec. 1222 (S.D. Cal. 1976) (R. Pyle, Bankr. Judge); In re DLB Dev. Corp., 1 Bankr. Ct. Dec. 1463 (S.D. Cal. 1975) (K. McWilliams, Bankr. Judge).

134. United States v. Miller, 317 U.S. 369, 373 (1942).

135. See text accompanymg notes 117-119 supra.

136. One court has attempted to value pledged corporate stock on a fair market basis. In re The Overmyer Co., 2 Bankr. Ct. Dec. 992 (S.D.N.Y. 1976) (R. Babitt, Bankr. Judge).

137. Murphy, Use of Collateral, supra note 50, at 1509.

138. U.C.C. $\$ 9-504$. 
In facing an analogous question, that of determining the value of collateral for purposes of permitting and regulating the debtor's use of collateral during the pendency of a Chapter XI proceeding, one bankruptcy court has held that the price to be received in a commercially reasonable disposition of collateral, rather than in a liquidation sale, is the proper measure of value. ${ }^{139}$ In In re American Kitchen Foods, Inc., the court went on to hold that conversion of receivables and inventory in the ordinary course of the operating busimess is the most commercially reasonable disposition of collateral and the debtor's right to use the equity in the collateral would be measured accordingly. ${ }^{140}$ This formulation is certainly helpful with regard to inventory and work in progress, ${ }^{141}$ but different problems arise when accounts receivable, equipment or fixtures have been pledged as security. The secured creditor cannot ignore the possibility that accounts receivables of a debtor-in-possession may convert at less than face value. ${ }^{142}$ With regard to equipment and fixtures used in the debtor's operations, there is no conversion in the ordinary course of business, and liquidation by sale at a discount in a gradual and orderly manner may yield the highest return. ${ }^{143}$ Stated simply, sale in the ordinary course of business is not necessarily the most commercially reasonable method of disposition.

One final problen in valumg collateral is the date on which valuation is to occur. The secured creditor is entitled to no less than the value of its collateral as of the date of the petition. ${ }^{14.4}$ The reorganization court must protect the secured creditor against diminution in the value of collateral during the course of the proceeding, when the collateral was retained at the debtor's behest. ${ }^{145}$ Where the collateral increases in value during the pendency of the proceeding, it has been held that the secured creditor, no less than the debtor, should benefit from the higher value. ${ }^{146}$ However, those instances where the increase

139. In re American Kitchen Foods, Inc., 2 Bankr. Ct. Dec. 715 (D. Me. 1976)

(C. Cyr, Bankr. Judge).

140. Id. at 722 .

141. See Reconstruction Fin. Corp. v. Kaplan, 185 F.2d 791 (1st Cir. 1950), where the debtor in possession was allowed to assemble raw materials into finished goods, thereby increasing their sales value.

142. The collectibility of accounts, once the debtor's financial problems become known, varies greatly among different indnstries and types of account debtors. For exanple, construction contractor accounts have a notoriously low pay out rate, while retail consnmer accounts may be liquidated at close to face value.

143. Murphy, Use of Collateral, supra note 50, at 1509.

144. In re New York, New Haven \& Hartford Ry. Co., 147 F.2d 40 (2d Cir. 1945).

145. In re Chicago, Rock Island \& Pac. R.R. Co., 545 F.2d 1087 (7th Cir. 1976); In $r e$ Third Ave. Transit Corp., 198 F.2d 703 (2d Cir. 1952). But see New Haven Inclusion Cases, 399 U.S. 392, 491-92 (1970) where it was suggested that bondholders of a railroad had assumed the risk that their rights were subject to the public interest.

146. See Sexton v. Dreyfus, 219 U.S. 339 (1911) where the creditor was allowed 
in value occurs through no intervention of the debtor ${ }^{147}$ should be distinguished from situations where the increase is occasioned by the debtor's operation of the business or ongoing management of the collateral. In the latter case, equity would seem to require that, if the debtor's and creditor's interest in the business assets can be separated, ${ }^{148}$ the debtor should benefit from the investment of time and labor during the proceeding. Where the creditor has sought relief from stay, an increase in collateral value from the date of the petition to the date of trial would, of course, enlarge the debtor's equity cushion and perhaps make relief from the stay less likely. If the increase is due to the debtor's efforts, this increase could also affect the court's consideration of the other three factors involved in the relief from stay proceeding. Specifically, the increase in value could indicate that the property is important to the debtor's business, ${ }^{149}$ that rehabilitation of the business is likely; ${ }^{150}$ and that continuation of the stay will not materially harm the position of the secured creditor. ${ }^{151}$ The lesson is that collateral may not be fixed in value at the date of the petition but should be evaluated under the particular circumstances of each stage of the proceedings. ${ }^{152}$ The secured creditor should be alert for factors that may alter the value of collateral once rehabilitative proceedings are commenced.

\section{IV}

\section{The Debtor's Response to a Complaint FOR RELIEF FROM THE AUTOMATIC STAY}

When a secured creditor files a complaint for relief from an automatic stay, the debtor must carry the burden of proof that the stay

to apply to his debt the interest which had accrued on pledged securities during the pendency of the proceeding.

In In re Pine Gate Assocs., Ltd., 3 Bankr. Ct. Dec. 301 (N.D. Ga. 1977) (W. Norton, Bankr. Judge), the court included in the value of collateral the increased value accrued during the Chapter XII proceeding, for purposes of determining "adequate protection" in a $\$ 461(11)$ cramdown. To hold otherwise, the court pointed out, would in effect give the debtor an option to purchase the collateral at a bargain price.

147. See Sexton v. Dreyfus, 219 U.S. 339 (1911).

148. For example, where parts suppliers for a manufacturer retain a security interest in certain raw materials, but not in finished inventory, the increase in value due to the debtor's assembly of goods should not be considered as value of the collateral. This separation of values, however, will rarely be possible as most commercial lenders take a security interest in all the debtor's goods, raw materials, inventory and work in progress, as well as the products and proceeds thereof.

149. See text accompanying notes 97-99 supra.

150. See text accoinpanying notes 87-95 supra.

151. See text accompanying notes 73-86 supra.

152. In re American Kitchen Foods, Inc., 2 Bankr. Ct. Dec. 715 (D. Me. 1976) (C. Cyr, Bankr. Judge). 
should be continued.153 An important question is whether the debtor can meet this burden by asserting affirmative defenses and counterclaims agamst the creditor designed to partially or completely offset the secured debt. The debtor will frequently have, or be able to devise, such counterclaims against the secured creditor. Fraud, negligence, breach of contract, usury, interference with prospective business advantage, securities fraud, antitrust violations-all are claims that a debtor might raise to challenge the debt. Allowing a debtor to raise these real or imagined claims, when a creditor files a complaint for rehef from the automatic stay, could flood the bankruptcy courts with complex trials-including jury trials ${ }^{154}$ - on every conceivable tort and contract counterclaim. Such a result does not accord with either the essential nature of a complaint for rehef from stay, that of a hearing on a preliminary imjunction, ${ }^{155}$ or with the intention of the drafters of the Bankruptcy Rules, who gave calendar priority to these hearings. ${ }^{156}$ On the other hand, it would be unfair to allow a secured creditor to obtain relief from a stay without giving the debtor an opportunity to explaim to the court that the creditor is owed less than claimed. The debtor may have equity in the property where none would be apparent absent consideration of the debtor's counterclaims. How these competing interests can be resolved is the subject of the next section of this Article.

\section{A. Procedural Nature of a Hearing on a Complaint for Relief from the Automatic Stay}

Since a complaint for relief from an automatic stay is an adversary proceeding governed by Part VII of the Bankruptcy Rules, ${ }^{157}$ it can be argued that all aspects of Part VII must apply to such a complaint. The debtor would be required to raise all affirmative defenses, under Bankruptcy Rule $712,{ }^{158}$ and all compulsory counterclaims, under Bank-

153. BanKRUPtCY Rules 10-601(c), 11-44(d), 12-43(d). See note 54 supra for partial text of these sections.

154. See Comment, Implied Consent To Summary Jurisdiction in Bankruptcy: The Forgotten Right to Jury Trial, 114 U. PA. L. REv. 256 (1965).

155. See In re Decker, 465 F.2d 294, 297 (3d Cir. 1972); In re Groundhog Mountain Corp., 1 Bankr. Ct. Dec. 923 (S.D.N.Y. 1975) (R. Babitt, Bankr. Judge).

156. BANKRUPTCY RULES 401(d), 601(d), 10-601(d), 11-44(d), 12-43(d), 13$401(d)$.

157. See text accompanying notes 51-54 supra.

158. This rule incorporates, with certain modifications, Rule 12(b) of the Federal Rules of Civil Procedure, which provides inter alia that "every defense in law or in fact, to a claim for relief in any pleading . . . shall be asserted in the responsive pleading thereto if one is required." This would, of course, imclude affirmative defenses. 5 C. Wright \& A. Miller, Federal Practice aNd Procedure 1347 (1972). 
ruptcy Rule $713,{ }^{159}$ in answer to the complaint for relief from an automatic stay. Furthermore, following this argument, the debtor would be permitted to raise all permissive counterclaims in response to the secured creditor's complaint. ${ }^{160}$

As a matter of procedural analysis, this argument has been questioned, inost notably by Bankruptcy Judge Babitt in his opinions in In re Groundhog Mountain Corp. ${ }^{161}$ and In re The Overmyer Co. ${ }^{162}$ Prior to the advent of the Bankruptcy Rules, matters relating to stays in bankruptcy proceedings were brought by motion. ${ }^{163}$ There was no provision for the granting of such relief upon a complaint. Judge Babitt held that the new requirement of filing a complaint merely "alters a inethod of procedure," and that a request for relief from an injunctive stay is not a claim sufficient to support a permissive counterclain under the Federal Rules. ${ }^{164}$ He noted further that such counter-

159. This rule incorporates Rule 13 of the Federal Rules of Civil Procedure, with certain modifications. One of these modifications is found in subsection (3) of Bankruptcy Rule 713, which provides that "when a trustee or receiver fails to set up a counterclaim through oversight, inadvertence, or excusable neglect, or when justice so requires, he may by leave of court set up the omitted counterclaim by amendment or by commencing a new adversary proceeding or separate action." A debtor, receiver or trustee under the various Chapters has all the rights and duties of a trustce in bankruptcy. Bankruptcy Act $\S \S 187,341,442,11$ U.S.C. $\$ \S 587,741,842$ (1970). It could, therefore, be argued that Bankruptcy Rule 713(3) obviates the debtor's need to set up its compulsory counterclaims in opposition to a complaint for relief from an automatic stay. Since leave of court is required, however, Rule 713(3) does not confer an unqualified right to set up such counterclaims in a separate proceeding, and assertion of the debtor's counterclaims might still be compulsory. It should additionally be noted that Rule 13 of the Federal Rules of Civil Procedure was held applicable in bankruptcy proceedings before the advent of the Bankruptcy Rules. Harris v. Capehart-Farnsworth Corp., 225 F.2d 268, 270 (8th Cir. 1955).

160. Permissive counterclaims are those which do not arise out of the transaction or occurrence that is the subject matter of the opposing party's claim. FED. R. Civ. P. $13($ b).

161. 1 Bankr. Ct. Dec. 923 (S.D.N.Y. 1975) (R. Babitt, Bankr. Iudge).

162. 2 Bankr. Ct. Dec. 992 (S.D.N.Y. 1976) (R. Babitt, Bankr. Judge).

163. See text accompanying notes 47-48 supra.

164. In re Groundhog Mountain Corp., 1 Bankr. Ct. Dec. 923, 924-25 (S.D.N.Y. 1975) (R. Babitt, Bankr. Judge), stating that a prayer for relief from a stay is not a "claim" since it is only defensive and does not seek affirmative relief from the court, citing Kearney v. A'Hearn, 210 F. Supp. 10, 20 (S.D.N.Y. 1962), aff'd per curiam, 309 F.2d 487 (2d Cir. 1962). Kearney involved a taxpayer's attempt to restrain the Internal Revenue Service from collecting certain tax deficiencies. This distinction between claims for affirmative relief and merely defensive actions has been recognized in bankruptcy cases holding that a creditor's prayer for relief from stays of enforcement does not constitute implied consent to summary jurisdiction. See Henkin v. United States, 229 F.2d 895, 897 (2d Cir. 1956); In re The Overmyer Co., 2 Bankr. Ct. Dec. 993, 994 (S.D.N.Y. 1976) (R. Babitt, Bankr. Judge); In re All American Burger, Inc., 2 Bankr. Ct. Dec. 763 (C.D. Cal. 1976) (R. Ordin, Bankr. Judge); In re Groundhog Mountain Corp., 1 Bankr. Ct. Dec. 923, 924 (S.D.N.Y. 1975) (R. Babitt, Bankr. Judge); In re Oceana Int'l, Inc., 376 F. Supp. 956, 960 (S.D.N.Y, 1974); Tamasha Town \& 
claims are not related to the merits of the relief from a stay action, but rather go to the merits of a suit to enforce the lien-a suit which the creditor hopes to bring if relieved of the stay. ${ }^{165}$ This later action would provide an appropriate forum for the debtor to raise relevant defenses and counterclaims.

Judge Babitt, in effect, reasons that all adversary proceedings need not be treated alike; that one must look to the purpose of each type of adversary proceeding to determme its true nature; and that, for the purpose of raising defenses and counterclaims, a pleading praying for relief from a stay is still a motion, as it was before the advent of the Bankruptcy Rules. Judge Babitt's opinions display admirable common sense and an equally adımirable awareness of historical development, but require the difficult conclusion that the drafters of the Bankruptcy Rules did not mean what the rules clearly say: that a proceeding to obtain rclief from a stay is an adversary proceeding requiring the parties to observe all of the requirements set forth in Part VII of the Bankruptcy Rules, including those concerning defenses and counterclaims. ${ }^{166}$

\section{B. Summary Jurisdiction to Consider Affirmative Defenses and Counterclaims to a Complaint for Relief from an Automatic Stay}

A more fundamental consideration, in determining whether affirmative defenses and counterclaims may be asserted against a complaint for relief from stay, is the summary jurisdiction of the bankruptcy court. Bankruptcy court jurisdiction is a creature of statute, limited by specific grants in the Bankruptcy Act. ${ }^{167}$ Nevertheless, the term "summary" jurisdiction may be a 1 misnoiner, ${ }^{168}$ particularly in view of the

Country Club v. McAlester Constr. Fin. Corp., 252 F. Supp. 80, 88 (S.D. Cal. 1966).

Whether the debtor's claim "arises out of" the subject matter of a complaint for relief from stay was held to be the determining factor in $I n$ re Fairway Wholesale, Inc., 2 Bankr. Ct. Dec. 1302 (D. Conn. 1976) (S. Seidman, Bankr. Judge). There the debtor counterclaimed, alleging a voidable preference, in response to a complaint for relief from stay to terminate a lease and licensing agreement. Since Rule 13(b) of the Federal Rules of Civil Procedure requires independent jurisdictional grounds for a permissive counterclaim, the court stated it would not have summary jurisdiction to hear the preference action, absent the party's consent.

165. In re Groundhog Mountain Corp., 1 Bankr. Ct. Dec. 923, 924-25 (S.D.N.Y. 1975) (R. Babitt, Bankr. Judge).

166. The Groundhog Mountain and Overmyer procedural analysis has not been universally adopted. In one reported decision, the debtor was permitted to raise an affirmative defense of usury to a secured creditor's complaint for relief from stay. In re Sal Ainato, Inc., 1 Bankr. Ct. Dec. 954 (D. Conn. 1975) (S. Seidman, Bankr. Judge).

167. Bankruptcy Act $\$ \$ 2,23,11$ U.S.C. $\$ \$ 11,46$ (1970).

168. Treister, What's in a Name-The Unhappy Tag of Summary Jurisdiction, 39 REF. J. 67 (1965). To speak of a bankruptcy court's summary jurisdiction is somewhat 
fact that Part VII of the Bankruptcy Rules, governing pleading and procedure in adversary proceedings, generally adopts the Federal Rules of Civil Procedure.

Summary jurisdiction in Chapter proceedings is substantially identical to jurisdiction in straight bankruptcy. ${ }^{168}$ The bankruptcy court has summary jurisdiction to adjudicate those matters that are either proceedings in bankruptcy, or controversies arising in proceedings in bankruptcy. In addition, the court may attain jurisdiction by consent of the parties to hear matters not otherwise cognizable. ${ }^{170}$ Ordinarily, defenses and counterclaims to a complaint for relief from stay do not fall into any of these categories.

The first situation, "proceedings in bankruptcy," is a "term of art referring to matters of the administration of the bankrupt's estate imcluding the allowance of claims and the reduction of the estate to money."171 A proceeding in bankruptcy is a "ruling internal to the bankruptcy administration on such questions as adjudication, section 21a examination, discharge, exemptions, allowance of claims, and disposition of dividends." ${ }^{172}$ The matters ordinarily raised by a defendant's affirmative defenses or counterclaims are not matters essential or "internal" to the administration of the bankrupt estate.

"Controversies arising in proceedings in bankruptcy" is also a "term of art referring to disputes over the property of the bankrupt in the actual or constructive possession of the court."173 Only controversies to determine "whether specific property belongs to the bankrupt estate" are classified as "controversies arising in proceedings in bankruptcy." Such controversies arise, for exainple, when a creditor seeks to "reclaim" a specific item of property in the custody of the bankruptcy

misleading since one thereby implies that the court may have jurisdiction that is not "summary." "All of the jurisdiction of a bankruptcy court acting strictly in character is summary." J. MACLACHLAN, HANDBOOK OF THE LAW OF BANKRUPTCY $\$ 194$, at 206 (1956) [hereinafter referred to as MAcLACHLAN].

169. See text accompanying notes 20-45 supra.

170. In re Essex Properties, Ltd., 430 F. Supp. 1112, 1115-16 (N.D. Cal. 1977); Tamasha Town \& Country Club v. McAlester Constr. Fin. Corp., 252 F. Supp. 80, 85-86 (S.D. Cal. 1966); In re All American Burger, Inc., 2 Bankr. Ct. Dec. 763, 76465 (C.D. Cal. 1976) (R. Ordin, Bankr. Judge).

171. Tamasha Town \& Country Club v. McAlester Constr. Fin. Corp., 252 F. Supp. 80, 85 (S.D. Cal. 1966).

172. MACLACHLAN, supra note $168, \S 361$, at $431-32$.

173. Tamasha Town \& Country Club v. McAlester Constr. Fin. Corp., 252 F. Supp. 80, 85 (S.D. Cal. 1966); see Katchen v. Landy, 382 U.S. 323, 336-38 (1966); Cline v. Kaplan, 323 U.S. 97 (1944). The chief reason for the distinctions between proceedings in bankruptcy and controversies in proceedings in bankruptcy is the determination of the appealability of interlocutory orders under $\$ 24$ of the Bankruptcy Act. MACLACHLAN, supra note 168, § 199, at 214-15. 
court from the bankruptcy estate. ${ }^{174}$ Ordinarily, the debtor's ownership of the encumbered property will not be contested by the secured creditor in a complaint for relief from stay. Therefore, to come withm the sunmary jurisdiction of the court, a defendant's counterclaims and affirmative defenses must be classified under a third category, as controversies arising at law or in equity over which the bankruptcy court does not have jurisdiction without consent of the secured creditor. ${ }^{175}$

Controversies between the debtor or bankrupt and a third party inay involve causes of action for damages and are subjects of summary jurisdiction where the third party, by consent, is deemed to have waived the right to have the controversy tried in a plenary suit in a court of proper jurisdiction. ${ }^{176}$ Consent nnay be expressed or nnay be implied either from a party's failure to timely object ${ }^{\mathbf{1 7 7}}$ or from a party's acts, such as filing a claim, whereby the party seeks soine affirmative relief from the bankruptcy court. ${ }^{178}$ Consistently, courts have held that the act of seeking relief froin a stay does not constitute such implied consent. ${ }^{179}$ Indeed, the secured creditor may utilize a range of procedural devices without forfeiting the right to object to summary jurisdiction. ${ }^{180}$

174. MacLachlan, supra note 168, 199.

175. See Bankruptcy Act § 23a, 11 U.S.C. § 46a (1970).

176. For a statement of the general rule providing for the right to a plenary suit, see Hollywood Nat'1 Bank v. Bumb, 409 F.2d 23 (9th Cir. 1969); In re 671 Prospect Ave. Holding Corp., 118 F.2d 453 (2d Cir.), cert. denied, 314 U.S. 642 (1941).

177. Bankruptcy Rule 915 sets forth the procedure for timely objection to the bankruptcy court's jurisdiction.

178. Peters v. Lines, 275 F.2d 919 (9th Cir. 1960); Inter-State Nat'l Bank v. Luther, 221 F.2d 382 (10th Cir. 1955); Floro Realty \& Inv. Co. v. Steem Elec. Corp., 128 F.2d 338 (8th Cir. 1942); Tamasha Town \& Country Club v. McAlester Constr. Fin. Corp., 252 F. Supp. 80 (S.D. Cal. 1966).

The authors take no position here on the question of whether a creditor's filing a claim in a bankruptcy proceeding constitutes consent to the exercise of summary jurisdiction. It should be noted that the Chapter XII rules require that any creditor whose claim is listed on the schedule of debts filed with the court (and prepared by the debtor) as "disputed, contingent, or unliquidated" must file a claim in order to participate in the proceeding. BANKRUPTCY RULE 12-30(b)(3). In these circumstances, filing a claim in a Chapter XII is arguably defensive and, therefore, may not be consent to sumınary jurisdiction for all purposes.

179. See Henkin v. United States, 229 F.2d 895 (2d Cir. 1956); In re All American Burger, Inc., 2 Bankr. Ct. Dec. 763 (C.D. Cal. 1976) (R. Ordin, Bankr. Judge); In re Groundhog Mountain Corp., 1 Bankr. Ct. Dec. 923 (S.D.N.Y. 1975) (R Babitt, Bankr. Judge); In re Oceana Int'l, Inc., 376 F. Snpp. 956 (S.D.N.Y. 1974); Tamasha Town \& Country Club v. McAlester Constr. Fin. Corp., 252 F. Supp. 80 (S.D. Cal. 1966).

180. In Tamasha Town \& Country Club v. McAlester Constr. Fin. Corp., 252 F. Supp. 80 (S.D. Cal. 1966), the secured creditor not only sought relief from the injunction against foreclosure, but also sought authorization to reclaim personal property; to have the debtor adjudicated a bankrupt; and to require the debtor to post a bond, to account, and to appear for an examination. All of these actions were held to be defensive in that they were directed to accomplishing a termination of restraints on the creditor. Also see In re All American Burger, Inc., 2 Bankr. Ct. Dec. 763 (C.D. Cal. 
There are two bases for these holdings: (1) The creditor is "compelled to apply to the bankruptcy court for permission to foreclose its lien" and cannot, therefore, be said to have consented to summary jurisdiction, ${ }^{181}$ and (2) the creditor's seeking relief from restraints imposed by the bankruptcy proceeding is purely defensive and does not invoke the court's jurisdiction to take affirmative steps on its behalf. ${ }^{182}$

The logical result of these holdings is that, unless a creditor expressly consents to the exercise of summary jurisdiction, the bankruptcy court has no authority to determine the validity of general defenses or counterclanins raised by a debtor in answer to a secured creditor's complaint for relief from an automatic stay.

Finding that the defenses and counterclaims of a debtor do not fall into any of the three traditional categories of bankruptcy court jurisdiction does not end the analysis. The scope of the court's summary jurisdiction in hearing a complaint for relief from a stay became an open question upon the adoption of the Bankruptcy Rules in 1973. These rules incorporate, into adversary proceedings, the law of affirmative defenses and counterclaims of the Federal Rules of Civil Procedure. ${ }^{183}$ In spite of firm pre-Bankruptcy Rules precedent for the proposition that seeking relief from a stay does not constitute consent to summary jurisdiction, ${ }^{184}$ post-rules bankruptcy courts have split on the question of their authority to adjudicate affirmative defenses and counterclaims asserted in a response to a complaint for relief from stay. In $\ln$ re Groundhog Mountain Corp. ${ }^{185}$ and In re The Overmyer Co. ${ }^{186}$ it was held that the Bankruptcy Rules requiring the secured creditor to file a complaint did not confer upon the debtor the right to raise affirmative defenses and counterclaims. ${ }^{187}$ In contrast, the bankruptcy court

1976) (R. Ordin, Bankr. Judge), where the creditor complained for relief froin the stay, conducted a rule 205 examination of the debtor's president and moved for sequestration of certain fees, all without being deemed to have consented to summary jurisdiction.

181. Henkin v. United States, 229 F.2d 895, 897 (2d Cir. 1956); In re Oceana Int'1, Inc., 376 F. Supp. 956, 960 (S.D.N.Y. 1974).

182. In re All American Burger, Inc., 2 Bankr. Ct. Dec. 763 (C.D. Cal. 1976) (R. Ordin, Bankr. Judge); In re Oceana Int'1, Inc., 376 F. Supp. 956 (S.D.N.Y. 1974); Tamasha Town \& Country Club v. McAlester Constr. Fin. Corp., 252 F. Supp. 80 (S.D. Cal. 1966). Even where a party is found to have consented to summary jurisdiction, there may be a further limit on the bankruptcy court's authority over litigation. The controversy must be related to the express purpose of causing "the estates of bankrupts . . . to be collected and distributed." In re Oceana Int'1, Inc., supra at 961, citing Bankruptcy Act § 2a(7), 11 U.S.C. \$ 11 (1970).

183. See BANKRUPTCy RULES 712 and 713, discussed in notes 158-159 supra.

184. See text accompanying notes 179-182 supra.

185. 1 Bankr. Ct. Dec. 923 (S.D.N.Y. 1975) (R. Babitt, Bankr. Judge).

186. 2 Bankr. Ct. Dec. 992 (S.D.N.Y. 1976) (R. Babitt, Bankr. Judge).

187. While Judge Babitt alluded to the possible jurisdictional grounds for this holding, the opinions did not expressly discuss the jurisdictional analysis of Tamasha or Henkin. See 1 Bankr. Ct. Dec. at 924-25; 2 Bankr. Ct. Dec. at 994. 
in In re Sal Amafo, Inc., ${ }^{188}$ and In re Sixth Avenue Investment \& Development $C o{ }^{189}$ permitted a debtor to raise counterclaims of usury in response to a creditor's complaint for relief from stay, although it does not appear that the creditors in these cases raised a timely objection to jurisdiction. ${ }^{190}$ Logically, the application of the new Bankruptcy Rules should not result in any expansion of bankruptcy court jurisdiction, ${ }^{191}$ but the requirement that the secured creditor file a complaint for relief from stay appears to imvite the debtor's assertion of counterclaims and affirmative defenses, accompanied by the debtor's argument that filing a complaint in the bankruptcy court results in implied consent to summary jurisdiction.

A recent district court decision applied the reasoning of Henkin v. United States ${ }^{192}$ and Tamasha Town \& Country Club v. McAlester Construction Finance Corp. ${ }^{193}$ in a post-rules context to prevent the debtor from raismg affirmative defenses and counterclaims on a complaint for relief from stay. In In re Essex Properties, $L t d .,{ }^{104}$ the secured creditor had commenced a real property foreclosure action in a Florida state court. The debtor filed a Chapter XII proceeding, thereby staying continuation of the foreclosure suit. ${ }^{195}$ In response to the creditor's complaimt for relief from stay, the debtor answered and raised certain affirmative defenses and counterclaims mcluding usury, negligence, breach of contract and fraud. The bankruptcy court's order granted the creditor's motion to strike the affirmative defenses and to dismiss the counterclaims. This order was upheld on review of the district court.

District Judge Orrick adopted Bankruptcy Judge Babitt's procedural analysis with regard to the Bankruptcy Rules: (1) The secured

188. 1 Bankr. Ct. Dec. 954 (D. Conn. 1975) (S. Seidman, Bankr. Judge).

189. 2 Bankr. Ct. Dec. 1222, 1224-28 (S.D. Cal. 1976) (R. Pyle, Bankr. Judge).

190. Bankruptcy Rule 915 provides that a party waives objection to jurisdiction if he does not make timely objection. As to what is "timely," compare In re Fairway Wholesale, Inc., 2 Bankr. Ct. Dec. 1302 (D. Conn. 1976) (S. Seidman, Bankr. Judge) (creditor deemed to have consented by filing a reply to debtor's counterclaim although creditor orally objected to jurisdiction at the time of trial) with Clime v. Kaplan, 323 U.S. 97, 99 (1944) (stated that a party is not deemed to have consented so long as formal objection is made at any time before entry of a final order).

191. Bankruptcy Rule 928 provides that the rules "shall not be construed to extend or limit the jurisdiction of courts of bankruptcy over subject matter." The enabling legislation for the Bankruptcy Rules provides that the "rules shall not abridge, enlarge, or modify any substantive right." 28 U.S.C. $\$ 2075$ (1970). Presumably, this would include any right a third party may have to a plenary proceeding.

192. 229 F.2d 895 (2d Cir. 1956).

193. 252 F. Supp. 80 (S.D. Cal. 1966).

194. 430 F. Supp. 1112 (N.D. Cal. 1977).

195. See BANRRUPTCY RULE 12-43, discussed in note 40 supra. 
creditor's complaint does not constitute a clain that would support counterclaims and affirmative defenses under Federal Rules 12 or 13; and (2) the debtor's defenses and counterclaims were not related to the relief sought by the secured creditor, namely, termmation of the automatic stay, but rather were directed to the validity of the creditor's security interest and other matters not before the bankruptcy court. ${ }^{100}$

More importantly, the district court held that the bankruptcy court had no summary jurisdiction to adjudicate the debtor's affirmative defenses and counterclaims on a creditor's complaint for relief from stay. The court noted that jurisdiction was unaffected by the Bankruptcy Rules governing adversary proceedings, ${ }^{197}$ and adopted the discussion of the three bases of suminary jurisdiction as set forth in Tamasha. ${ }^{108}$ The court found, without discussion, that the inatters raised by the debtor were not administrative inatters contemplated by the term "proceedings in bankruptcy," nor were they disputes over ownership of property so as to constitute "controversies in proceedings in bankruptcy." Finally, the court agreed with the Tamasha and Henkin reasoning that, by seeking relief from the restraints of a bankruptcy proceeding, the secured creditor did not impliedly consent to summary jurisdiction. ${ }^{100}$ The court thus affirmed the post-rules holdings of Groundhog and Overmyer. The Essex Properties decision indicates that, regardless of the procedural requireinent that the secured creditor file a complaint for relief froin stay, the creditor's action is essentially defensive and compelled by the intervention of the bankruptcy proceedimg itself. ${ }^{200}$ It does not constitute the creditor's consent to the jurisdiction of the court so as to permit adjudication of affirmative defenses and counterclaims raised by the debtor.

The Essex Properties decision is a fortunate result from the standpoint of bankruptcy administration. Were the law otherwise, and debtors permitted to raise all maimer of defenses and counterclaims in

196. In re Essex Properties, Ltd., 430 F. Supp. 1112, 1114-15 (N.D. Cal. 1977).

197. Id. at 1115, citing BANKRUPTCY RULE 928.

198. See text accompanying notes 169-182 supra.

199. In re Essex Properties, Ltd., 430 F. Supp. 1112, 1116 (N.D. Cal. 1977); Tamasha Town \& Country Club v. McAlester Constr. Fin. Corp., 252 F. Supp. 80, 86 (S.D. Cal. 1966).

200. In its discussion of Bankruptcy Rule 713, the Essex Properties court placed some importance on the fact that a Florida state court foreclosure action was pending at the time of the Chapter XII proceeding. The absence of a pending state court proceeding, however, would not vitiate this portion of the opinion because the debtor would be free to pursue its counterclaim in any other proper forum in which it initiated an injunction or damages action. Furthermore, as the second half of the Essex Properties decision holds, the bankruptcy court simply does not have jurisdiction to adjudicate the merits of a usury counterclaim. The absence of a pending proceeding in some other forum does not create jurisdiction where it otherwise would not exist. 
response to a complaint for relief from an automatic stay, every such complaint would provoke a barrage of counterclaims by the debtor, requiring a comphicated trial.in the bankruptcy court, possibly even a jury trial. ${ }^{201}$ However, the current limitations on bankruptcy court jurisdiction, as recognized by the Essex court, preclude this. ${ }^{202}$

\section{Affirmative Defenses and Counterclaims: A Compromise Solution}

If the debtor cannot raise general defenses and counterclaims in a creditor's action for relief from a stay, what issues can the debtor raise? The debtor should address the same four issues that the creditor must raise: Does the debtor have an equity interest in the encumbered property? Will continuation of the stay cause harm to the creditor? Does the debtor have a reasonable chance of rehabilitation? Does the debtor need the encumbered property to continue its business? ${ }^{203}$ In many cases, the creditor will liave to concede the debtor's need for the property and will recognize the court's reluctance to determine early in a proceeding that a debtor has no chance of reliabilitation. This ineans that the significant points of dispute will be the debtor's equity and the creditor's mjury.

201. Ordinarily, the right to jury trial in bankruptcy cases is extremely limited. Barton v. Barbour, 104 U.S. 126, 133-34 (1881). The Bankruptcy Act confers a right to jury trial only in contests on an involuutary petition. Bankruptcy Act $\$ 19,11$ U.S.C. $\$ 42$ (1970). In re Arinont Knitting \& Undergarinent Co., 182 F.2d 740 (2d Cir. 1950). Two important Supreme Court cases, however, raise the prospect that this limited right to jury trial should be expanded. See Dairy Queen, Inc. v. Wood, 369 U.S. 469 (1962); Beacon Theatres, Inc. v. Westover, 359 U.S. 500 (1959); Comment, Implied Consent to Summary Jurisdiction in Bankruptcy: The Forgotten Right to Jury Trial, 114 U. PA. L. REv. 256 (1965). These cases stand firmly for the proposition that the constitutional right to a jury trial in inatters at law caunot be abrogated simply because a case also involves equitable relief. The applicability of this authority in bankruptcy cases may be doubted since the Supreme Court distinguished these cases in Katchen v. Landy, 382 U.S. 323, 339 (1966), saying: "In neither Beacon Theatres nor Dairy Queen was there involved a specific statutory scheme contemplating the proinpt trial of a disputed claim without the imtervention of a jury." Katchen involved an action for recovery of a preference, a matter clearly contemplated by the "specific statutory scheme" of the Bankruptcy Act. The Katchen case may, therefore, be questionable authority on the jury trial issue where the action before the bankruptcy court is not so intimately connected to the statutory scheme-for example, an antitrust or securities fraud action. Can a "specific statutory scheme" override the constitutional right to jury trial in those circumstances? Commenting upon Katchen, in a recent case on the right to jury trial, the Supreine Court said: "[T]he Court recognized that a bankruptcy court has been traditionally viewed as a court of equity, and that jury trials would 'dismember' the statutory scheme of the Bankruptcy Act." Curtis v. Loether, 415 U.S. 189, 195 (1974). See also Ross v. Bernhard, 396 U.S. 531 (1970).

202. The drafters of the proposed new Bankruptcy Act should consider what effect expanded bankruptcy court jurisdiction would have on actions brought by creditors to obtain relief from stays. See Section VI infra.

203. See text accompanying notes 59-102 supra. 
Since the equity question is so important, must the bankruptcy court, because of its limited jurisdiction, turn a deaf ear to the debtor's argument that it does have equity in the encumbered property if allowed to set off its counterclaims against the secured debt? The answer is yes and no. Yes, the court must turn a deaf ear to the debtor's plea for an affirmative judicial determination on its claimed offsets since the court has no jurisdiction to make this determination. No, the court need not and should not totally discount the debtor's defenses. ${ }^{204}$ To do so would ignore the real nature of a proceeding to obtaim relief from a stay which, as suggested by Judge Babitt from the historical antecedents of the Bankruptcy Rules, is akin to a hearing on a prelimimary injunction. ${ }^{205}$

As in a hearing on a preliminary injunction, ${ }^{206}$ the court in its discretion may consider any factor that is relevant to the relative equities of the parties and aids the determmation that must be made with regard to balancing the hardships. When a creditor files a complaint for relief from a stay, the burden of justifying the stay falls on the debtor. ${ }^{207}$ If the debtor wishes to raise alleged offsets as a defense against the secured debt, it should not be necessary that a right to such an offset be conclusively proved. The debtor should be able to meet this burden if it can be shown that there is a substantial likelihood of prevailing on the claims against the creditor. This is similar to the burden that must ordinarily be met by an applicant for a preliminary injunction. ${ }^{208}$ It is also a logical standard of proof since the debtor's offsets are relevant to the issue of the debtor's "equity." ${ }^{209}$ Though the value of the secured creditor's collateral is certainly an important consideration, the bankruptcy court will not make a final determination of this value in a relief from stay proceeding. A complaint for relief from the auto-

204. As noted by Judge Orrick, a bankruptcy court "may grant a debtor a limited right to introduce evidence concerning the debtor's equity in mortgaged property . .." In re Essex Properties, Ltd., 430 F. Supp. 1112, 1115 (N.D. Cal. 1977).

205. In re Groundhog Mountain Corp., 1 Bankr. Ct. Dec. 923, 924 (S.D.N.Y. 1975) (R. Babitt, Bankr. Judge); see In re Decker, 465 F.2d 294 (3d Cir. 1972). Sec also text accompanying notes 83-84 supra.

206. 11 C. Wright \& A. Miller, Federal Practice and Procedure $\S 2948$ (1973).

207. See, e.g., Foust v. Munson S.S. Lines, 299 U.S. 77 (1936); In re Prudence Co., 90 F.2d 587 (2d Cir. 1937); In re Zeckendorf, 326 F. Supp. 182 (S.D.N.Y. 1971); BANKRUPTCY RULES 601(c), 10-601(c), 11-44(d), 12-43(d), 13-401(d). See also text accompanying note 153 supra.

208. 11 C. Wright \& A. Miller, Federal Practice and Procedure $§ 2948$ (1973).

209. See In re Sixth Ave. Inv. \& Dev. Corp., 2 Bankr. Ct. Dec. 1222 (S.D. Cal. 1976) (R. Pyle, Bankr. Judge), where the debtor's counterclaim for usury was relevant in determining the amount of the debt and, hence, the debtor's equity in the property. 
matic stay does not involve the court in an extensive valuation hearing. ${ }^{210}$ The court determines no more than whether the debtor is likely (or unlikely) to have an equity in the encumbered property. It is, therefore, reasonable to require the debtor to prove only the likelihood of prevailmg on the claims against the secured creditor.

The rule then should be that in proceedings on a complaint for relief from an automatic stay the debtor may not seek, by affirmative defense or counterclaim, determination on the merits of causes of action against the plaintiff creditor, but may raise the likelihood of prevailing on such causes of action as a defense to the creditor's allegation that the debtor has no equity in encumbered property or that the creditor will suffer from continuation of the stay. This rule has numerous advantages for the court and for the parties. First, it permits the debtor to present claims against a creditor without having to ask the court to adjudicate defenses and counterclaims over which it has no jurisdiction. Second, it does not require a full hearing on the merits of the debtor's claims and is thus consistent with the speedy remedy contemplated by the drafters of the Bankruptcy Rules. ${ }^{211}$ Third, it avoids the problem of the possible right to jury trial ${ }^{212}$ by keeping the hearing on a complaint for relief from stay within the bounds of traditional equity jurisdiction. Fimally, it permits the reconciliation of judicial precedents that might otherwise seem inconsistent.

Groundhog Mountain ${ }^{213}$ illustrates the first part of the rule. The bankruptcy court does not have jurisdiction to determine general defenses and counterclains in an action for relief from a stay. Sal Amato $^{214}$ illustrates the second part of the rule. A debtor may raise the likelihood of prevailing on such counterclaims as a response to certain allegations by the creditor, including the allegation that the debtor lacks equity in the encumbered property. ${ }^{215}$ This rule will allow the court to consider all the facts, and then proceed to an equitable determination as to whether the secured creditor ought to be relieved of the burden imposed by the automatic stays in bankruptcy proceedings.

210. Compare the valuation hearing possible under $\S 57 \mathrm{~h}$ of the Bankruptcy Act, 11 U.S.C. 93 h (1970).

211. Bankruptcy Rules 401(d), 601(d), 10-601(d), 11-44(d), 12-43(d), 13-401

(d) give calendar priority to actions for relief from the automatic stays.

212. See note 201 supra.

213. 1 Bankr. Ct. Dec. 923 (S.D.N.Y. 1975) (R. Babitt, Bankr. Judge). See text accompanying notes $161-165$ supra.

214. 1 Bankr. Ct. Dec. 954 (D. Conn. 1975) (S. Seidman, Bankr. Judge). See text accompanying uote 188 supra.

215. Compare Georgia Jewelers, Inc. v. Bulova Watch Co., 302 F.2d 362 (5th Cir. 1962), with Harris v. Capehart-Farnsworth Corp., 225 F.2d 268 (8th Cir. 1955). 


\section{Beyond Essex Properties: Jurisdiction to Adjudicate Bankruptcy-Related Affirmative Defenses and Counterclaims}

After Essex Properties, the question remains whether certain debtor defenses or counterclaims may be cognizable by the bankruptcy court on a complaint for relief from stay, either because such claims are "controversies in proceedings in bankruptcy" or because such claims fall within the court's equitable power to determine the validity, priority and extent of liens on property in its custody. Controversies in proceedings in bankruptcy arise when a third party contends that certain property is not part of the bankruptcy estate although the bankruptcy court has custody of it or the trustee seeks summarily to possess it. $^{216}$ This situation may arise where a third party initiates a reclaination proceeding. ${ }^{217}$ Ordinarily, the assertion by a third party of a valid lien on the property in the possession of the court would not qualify as an assertion of "title or possessory rights" in property"18 that may be summarily adjudicated, since the assertion of a lien does not call into question title to the property or the right to possess it. A more difficult case, however, is presented when a third party asserts rights in an intangible asset. For exainple, would a third party's assertion of the right to use a trade naine, if such a right was acquired in a franchise agreement with the debtor, constitute a controversy in a proceeding in bankruptcy? ${ }^{219}$ If the third party filed a complaint for relief from stay, could the debtor raise affirmative defenses and counterclaims intended to adjudicate the validity of the franchise agreement itself? The answer to this jurisdictional question could turn on the esoteric inquiry of whether rights under the franchise agreennent were in the constructive possession of the bankruptcy court.

Essex Properties tells us that a debtor faced with a creditor's complaint for relief from stay may not adjudicate all defenses and counterclaims that would ordinarily be available against the creditor. Yet, to the extent that the debtor is able to raise defenses and counterclaims that fall within the court's power, under the custodia legis principle, to determine the nature of liens upon property in its possession, the

216. MACLACHLAN, supra note 168 , $\$ 361$, at $431-32$ (1956).

217. Id. § 199, at 215.

218. Id.

219. A similar issue was raised by In re All American Burger, Inc., 2 Bankr. Ct. Dec. 763, 765 (C.D. Cal. 1976) (R. Ordin, Bankr. Judge) where a Chapter XI debtor filed a complaint to determine the validity of a franchise agreement and to terminate a third party's rights under the agreement. The court could not find any basis on which to hold that the debtor "has any more title or possession to the subject matter" than the third party and concluded that it had no summary jurisdiction. 
creditor seeking relief from stay to foreclose a lien may be forced to litigate the validity and extent of that lien in the bankruptcy court.

For example, one question is the power of the bankruptcy court, on a complaint for relief from stay, to hear debtor defenses based on its voiding powers under sections 60, 67 or 70 of the Bankruptcy Act. Ordimarily, a third party is entitled to a plenary proceeding to determine preference actions under section 60 , where the property alleged to liave been preferentially transferred is not in the possession of the bankruptcy court. ${ }^{20}$ For instance, where a creditor receives $\$ 1,000$ in cash within four months of bankruptcy under circumstances that would render the transfer voidable as a preference, the trustee or debtor may not initiate a summary proceeding to recover the casli. The question arises whether the creditor's riglits to a plenary proceeding can be altered where, rather than receiving casl, the creditor receives a $\$ 1,000$ lien on real property and the real property passes into the custody of the bankruptcy court. In In re Carl Ahlers, Inc., ${ }^{221}$ Judge Babitt held that the bankruptcy court had no jurisdiction to liear an action to void a lien on real property where the real property was within the possession of the court. ${ }^{222}$ A logical arguinent could be inade that the property in dispute is the lien, not the real property itself, and that the lien is an intangible asset that has not passed into the custody of the bankruptcy court because it is held by an adverse claimant. ${ }^{223}$

On the other hand, it is generally accepted that the bankruptcy court may determine the validity, priority, and extent of liens on property in its possession. ${ }^{224}$ Is an action to void a preferential lien an action to determine the validity of that lien? This is troublesome where the lien is otherwise valid under state law and is not voidable absent a bankruptcy proceeding. Courts liave held, without discussion, that the bankruptcy court may summarily adjudicate a preference

220. Katchen v. Landy, 382 U.S. 323 (1966); Bankruptcy Act $\S 606,11$ U.S.C. $\S 96(1970)$.

221. 2 Bankr. Ct. Dec. 398 (S.D.N.Y. 1976) (R. Babitt, Bankr. Judge).

222. In In re Fairway Wholesale, Inc., 2 Bankr. Ct. Dec. 1302 (D. Conn. 1976) (S. Seidman, Bankr. Judge), the court stated that where a creditor filed a complaint for rehef from stay, the debtor's counterclaim alleging a voidable preference did not "arise out of" the creditor's complaint and therefore was not a compulsory counterclain for which the bankruptcy court had jurisdictiou. Independent jurisdictional grounds were necessary for such a "permissive" counterclaim. The court in Fairway Wholesale, however, did not confront the issue faced in In re Carl Ahlers, Inc., 2 Bankr. Ct. Dec. 398 (S.D.N.Y. 1976), since the tangible property that the debtor was alleged to have preferentially transferred was not in the custody of the court.

223. Cf. Harrison v. Chamberlin, 271 U.S. 191 (1926) (bankruptcy court is without jurisdiction to determine in a summary proceeding rights to property held adversely to the bankrupt estate).

224. 5A H. REMINGTON, BANKRUPTCY $\$ \$ 2522.10$ and 2357 (5th ed, 1953 \& Supp. 1977). 
action to void a lien where the tangible property encumbered by the lien is in the custody of the court. 225 One assumes that these courts would not permit summary adjudication of a preference action to recover cash held by a third party. The distinction between a transfer of cash and the transfer of a lien must rest, therefore, on the custodia legis principle. ${ }^{226}$ While Essex Properties and the compromise rule suggested here resolve some of the questions relating to the debtor's affirmative defenses and counterclaims, several issues remain for future judicial resolution.

\section{V \\ FRAMING AN ORDER FOR RELIEF FROM THE STAY}

Having heard the relevant issues on a complaint for relief froin stay, the bankruptcy court may determine that continuing the stay against lien enforceinent would not be justified. The court may be reluctant, however, to allow the secured creditor to foreclose if proceeds from the sale of collateral will be less than the amount of the debt, thus permitting the creditor to file a claim in the bankruptcy proceeding or to pursue other items of security to the extent of the deficiency. This problein would arise whenever the secured creditor is entitled, under applicable state law and by the agreement with the debtor, to recover a deficiency to the extent the foreclosure sale proceeds fail to satisfy the indebtedness. ${ }^{227}$ At least two bankruptcy courts have faced the problein of the secured creditor obtaining relief from the automatic stay, conducting a foreclosure sale of real property, and then seeking to realize upon an additional security interest in rents to satisfy the deficiency. In In re Sonny Martini Inns, Inc., ${ }^{228}$ the court found that it was unfair to allow the secured creditor to recover accrued rents, which would otherwise go to the debtor, merely because it had

225. E.g., In re Meredosia Harbor \& Fleeting Serv., Inc., 545 F.2d 583 (7th Cir. 1976); In re Beedle-Whiton, 132 F. Supp. 558 (D. Minn. 1955).

226. See generally Continental Ill. Nat'l Bank \& Trust Co. v. Chicago, Rock Island \& Pac. Ry. Co., 294 U.S. 648, 675-76 (1935) (bankruptcy court empowered to enjoin such a sale in order to preserve assets under its control); Isaacs v. Hobbs Tie \& Timber Co., 282 U.S. 734 (1931).

227. California Uniform Commercial Code $\$$ 9504(2) provides that the debtor is liable for any deficiency unless otherwise agreed. Where the creditor forecloses a real property lien by means of judicial foreclosure proceedings, the creditor may seek a deficiency judgment within certain fair market value limits. See CAL. Crv. Proc. CoDE $\S 726$ (West Supp. 1977). No deficiency judgment may be sought against the debtor where the secured creditor forecloses a real property lien by sale under a power of sale in a trust deed or mortgage. CAL. Civ. Proc. CODE $\S 580 \mathrm{~d}$ (West 1976). The creditor, however, may resort to other items of security to the extent his debt is not satisfied by sale of the real property under a power of sale. Hatch v. Security-First Nat'l Bank, 19 Cal. 2d 254, 120 P.2d 869 (1942).

228. 2 Bankr. Ct. Dec. 642 (S.D. Texas 1976) (J. Blinn, Bankr. Judge). 
successfully bid low at the foreclosure sale. The court required the secured creditor to prove the claim for the deficiency. In In re Capri Development Co., ${ }^{229}$ Judge Katz attempted to minimize the secured creditor's ability to create a low bid shortfall. The court held that the findings of property value made in the hearing on complaint for rehef from stay were res judicata, and therefore binding on the creditor for purposes of determining a deficiency. ${ }^{230}$

One repercussion of the Essex Properties decision is to undermine the Capri Development solution to the problem of deficiencies. If the filing of a complaint for relief from stay does not constitute consent by the secured creditor to summary jurisdiction, then factual fimdings in that hearing should not be res judicata for purposes other than determining the propriety of relief from stay. The debtor, however, is not remediless and, again, it is helpful to regard the hearing for relief from stay as analogous to a hearing on a prelininary imjunction..$^{231}$ Where the court is concerned that the probable value of the property, as determined in the hearing on relief from stay, may be arbitrarily altered by a low bid at a foreclosure sale, and that granting relief from the stay may operate inequitably against the debtor, the bankruptcy court as a court of equity may enter an order that conditions relief from the stay. ${ }^{232}$ The court could grant the secured creditor relief only upon the condition that it agree not to pursue the debtor or other available property for any deficiency in excess of foreclosure sale proceeds. There is a substantial distinction between such a conditional order granting relief froin stay and an attempt to declare the court's findings to be of res judicata effect. A res judicata determination would make it impossible for the secured creditor to pursue guarantors of the debt or to pursue items of security that were not involved im the principal debtor's bankruptcy proceeding.

Counsel for secured creditors and for debtors might also consider framing a wide variety of conditional orders for relief from stay. ${ }^{233}$ For example, it may be too early in the proceeding to grant the creditor

229. 2 Bankr. Ct. Dec. 1294 (S.D. Cal. 1976) (H. Katz, Bankr. Judge).

230. Id. at 1294.

231. 8 C. Wright \& A. Miller, Federal Practice and Procedure, $\$ 2243$ (1970).

232. In In re Sixth Ave. Inv. and Dev. Co., 2 Bankr. Ct. Dec. 1222 (S.D. Cal. 1976) (R. Pyle, Bankr. Judge), the court granted relief from the stay upon the condition that the secured creditor bid in at the sale an amount equal to the value of the property as determined by the hearing on the complaint for rehef from stay. In certain circumstances, however, this type of conditional order may be fatal to the secured creditor's right to pursue third party guarantors.

233. See discussion of In re American Kitchen Foods, Inc., text accompanying notes 101-102 supra. 
relief to foreclose, but counsel for the creditor may wish to place a time limit on the debtor's continued protection from the stay. ${ }^{234}$ Similarly, counsel for the secured creditor should keep in mind that the automatic stays operate until the case is closed or dismissed, ${ }^{235}$ and may therefore wish to condition contmuation of the stay upon the creditor's receipt of some payment of secured debt during the course of the proceeding.

\section{VI \\ A Redrafting of the Automatic Stay Provision of the Proposed Bankruptcy Legislation}

As this Article is being written, legislation is pending in Congress that would completely rewrite the bankruptcy law of the United States. The most recent version of that legislation is H.R. $8200,{ }^{230}$ and the automatic stay provision of that bill is contained in its section $362 . .^{237}$

234. See, e.g., In re Triangle Inn Assocs., 2 Bankr. Ct. Dec. 1670 (E.D. Va. 1976) (H. Bonney, Jr., Bankr. Judge), where the court denied relief from the stay but ordered the debtor to submit a plan within three months.

235. BANKRUPTCY RULES 11-44(b), 10-601(b), 12-43(b). A Chapter XI case is ordinarily closed upon confirmation of a plan of arrangement, although jurisdiction may be retained for limited purposes. Bankruptcy Act $\$ 367(4)$, 11 U.S.C. $\$ 767(4)$ (1970). A Chapter XII proceeding is similarly dismissed upon confirmation of a plan. Bankruptcy Act $\$ 477,11$ U.S.C. $\$ 877$ (1970). A Chapter X case is not closed until consummation of the plan. Bankruptcy Act $\$ 228(4), 11$ U.S.C. $\$ 628(4)$ (1970).

236. H.R. 8200, 95th Cong., 1st Sess. (1977).

237. Section 362 of H.R. 8200 reads as follows:

(a) Except as provided in subsection (b) of this section, a petition filed under section 301,302 , or 303 of this title operates as a stay, applicable to all entities, of -

(1) the commencement or continuation, including the issuance or employment of process, of a judicial, administrative, or other proceeding agamst the debtor that was or could have been commenced before the commencement of the case under this title;

(2) the enforcement, against the debtor or against property of the estate, of a judgment obtained before the commencement of the case under this title;

(3) any act to obtain possession of property of the estate or of property from the estate;

(4) any act to create, perfect, or enforce any lien against property of the estate;

(5) any act to create, perfect, or enforce against property of the debtor any lien to the extent that such lien secures a claim that arose before the commencement of the case under this title;

(6) any act to collect or recover a claim against the debtor that arose before the commencement of the case under this title; and

(7) the setoff of any debt owing to the debtor that arose before the commencement of the case under this title against any claim against the debtor.

(b) The filing of a petition under section 301,302 , or 303 of this title does not operate as a stay-

(I) under subsection (a) of this section, of the commencement or 
Substantial revision of subsections (d), (e), (f) and ( $g$ ) of proposed section 362 is in order, ${ }^{238}$ and the authors, therefore, propose the following redrafting of those sections:

(d) Upon motion of a party in interest, after a final hearing,

continuation of a criminal action or proceeding against the debtor;

(2) under subsection (a) of this section, of the collection of alimony, maintenance, or support from property that is not property of the estate;

(3) under subsection (a) of this section, of any act to perfect an interest in property to the extent that the trustee's rights and powers are subject to such perfection under section 546(a) of this title;

(4) under subsection (a) (1) of this section, of the commencement or continuation of an action or proceeding by a governmental unit to enforce such governmental unit's police or regulatory power; or

(5) under subsection (a) (2) of this section, the enforcement of a judgment, other than a money judgment, obtained in an action or proceeding by a governmental unit to enforce such governmental unit's police or regulatory power.

(c) Except as provided in subsections (d), (e), and (f) of this section-

(1) the stay of an act against property of the estate under subsection (a) of this section continues until such property is no longer property of the estate; and

(2) the stay of any other act under subsection (a) of this section continues until the earliest of-

(A) the time the case is closed;

(B) the time the case is dismissed; and

(C) if the case is a case under chapter 7 of this title concerning an individual or a case under chapter 9,11 , or 13 of this title, the time a discharge is granted or denied.

(d) On request of a party in interest, after notice and a hearing, and for cause, including the lack of adequate protection of an interest in property of such party in interest, the court shall grant relief from the stay provided under subsection (a) of this section, such as by terminating, annuling, modifying, or conditioning such stay.

(e) Thirty days after a request under subsection (d) of this section for relief from the stay of any act against property of the estate under subsection (a) of this section, such stay is terminated with respect to the party in interest making such request, unless the court, after notice and a hearing, orders such stay continued in effect pending, or as a result of, a final hearing and determination under subsection (d) of this section. A hearing under this subsection may be a preliminary hearing, or may be consolidated with the final hearing under subsection (d) of this section. If the hearing under this subsection is a preliminary hearing, the court shall order such stay so continued if there is a reasonable likelihood that the party opposing relief from such stay will prevail at the final hearing under subsection (d) of this section.

(f) The court, without a hearing, shall grant such relief from the stay provided under subsection (a) of this section as is necessary to prevent irreparable damage to the interest of an entity in property, if such interest will suffer such damage before there is an opportunity for notice and a hearing under subsection (d) or (e) of this section.

(g) In any hearing under subsection (d) or (e) of this section concerning relief from the stay of any act under subsection (a) of this section, the party opposing such relief has the burden of proof on the issue of adequate protection.

238. Since this Article is concerned with relief from the automatic stay provisions, subsections (a), (b), and (c) of proposed $\$ 362$, which define the scope of the automatic stay under H.R. 8200, are not treated. 
on adequate notice to the trustee and any other necessary parties, and for cause, the court shall terminate, annul, modify or condition or otherwise grant relief from the stay provided under subsection (a) of this section. At a fimal hearing, a party seeking continuation of the stay must show that he is entitled thereto. A motion under this subsection shall take precedence on the court's calendar over all matters except older matters of the same character.

(e) Thirty days after service of moving papers under subsection (d) of this section, the stay provided under subsection (a) of this section is termmated with respect to the party making the motion under subsection (d) of this section, unless the court orders that the stay be continued in effect either (1) as a result of a final hearing under subsection (d) of this section or (2) pending the determination of the court on a motion made under subsection (d) of this section and after a preliminary hearing upon motion of a party opposing relief from the stay. Said party opposing relief from the stay shall give the party seeking relief from the stay five days' notice, or such shorter notice as the court may prescribe, of a preliminary hearing under this subsection (e), and, if a final hearing under subsection (d) of this section is set for a date within thirty days from the service of moving papers under subsection (d) of this section, said party opposing relief from the stay shall schedule the preliminary hearing for the same time as the final hearing. A party seeking continuation of the stay at a preliminary hearing under this subsection must show that there is a reasonable likelihood that he will prevail at the final hearing.

(f) In exceptional circumstances, the court may terminate, annul, modify, condition or otherwise grant relief from the stay provided in subsection (a) of this section without written or oral notice to the adverse party if (1) it clearly appears from specific facts shown by affidavit or by a verified complaint that immediate and irreparable injury, loss, or damage will result to the plaintiff before the adverse party or his attorney can be heard in opposition, and (2) the plaintiff's attorney certifies to the court in writing the efforts, if any, which have been made to give the notice and the reasons supporting his claim that notice should not be required. The party obtaining relief under this subsection shall give written or oral notice thereof as soon as possible to the trustee and to such other parties as the court may direct and, in any event, shall forthwith mail or deliver to such person or persons a copy of the order granting relief. On two days notice to the party who obtained relief from a stay provided by this rule without notice or on such shorter notice to that party as the court may prescribe, any party in interest may appear and move its reinstatement, and in that event the court shall proceed to hear and determine such motion as expeditiously as the ends of justice require.

(g) In ruling upon any motion made under subsection (d) or 
(e) of this section, the court shall not order continuation of the stay prescribed in subsection (a) of this section if it finds that adequate protection has not been provided for the party seeking relief from the stay.

The redrafted language has several significant advantages over the version contained in H.R. 8200. These include:

1. H.R. 8200 does not specify the procedural method by which a party in interest would request relief froin the stay of section 362 . As redrafted, subsection (d) specifies that a request for relief from the stay would be made by motion. In this regard, it departs from the current Bankruptcy Rules, which require that relief from a stay be sought by the filing of a complaint, ${ }^{239}$ although it conforms to the procedure in force prior to the advent of the Bankruptcy Rules. ${ }^{240}$ As noted herein, the requirement that a complaint be filed has caused significant difficulties in the administration of bankruptcy estates because when a creditor or other interested party seeks relief from the bankruptcy stay, this necessarily sets in inotion the entire adversary machinery under Part VII of the Bankruptcy Rules. ${ }^{241}$ It invites a party opposing such relief from stay to respond by filing affirmative defenses under Bankruptcy Rule 712 and counterclaims under Bankruptcy Rules 713, thereby using this procedural inechanism to raise all inanner of claims-fraud, breach of contract, usury, negligence, and the like-in an effort to forestall prompt action on the request for relief from stay. ${ }^{242}$

Under the present Act, bankruptcy courts are protected froin being mired in extensive litigation because they are courts of limited jurisdiction. Suminary jurisdiction under the Chandler Act would not ordinarily extend to counterclaims and affirmative defenses filed in response to a complaint for relief from stay. ${ }^{243}$ However, if the bankruptcy courts become courts of general jurisdiction under the proposed bankruptcy legislation, ${ }^{244}$ and if requests for relief from stay contimue

239. BANKRUPTCY Rules 401(d), 601(c), 701(6), 8-501(c), 8-601(5), 9-4(c), 9-36(4), 10-601(c), 10-701(5), 11-44(d), 11-61(a)(5), 12-43(d), 1260(a)(5), 13-401 (d), and 13-701(a) (6).

240. See In re Groundhog Mountain Corp., 1 Bankr. Ct. Dec. 923 (S.D.N.Y. 1975) (R. Babitt, Bankr. Judge).

241. See text accompanying notes 157-160 supra.

242. Id. See also, In re The Overmyer Co., 2 Bankr. Ct. Dec. 992 (S.D.N.Y. 1976) (R. Babitt, Bankr. Judge).

243. See text accompanying notes 167-182 supra, and cases cited in note 179 supra.

244. Section 1471 of H.R. 8200 provides:

(a) Except as provided in subsection (b) of this section, the bankruptcy courts shall have origimal and exclusive jurisdiction of all cases under title 11 .

(b) Notwithstanding any Act of Congress that confers exclusive jurisdiction on a court or courts other than the bankruptcy courts, the bankruptcy 
to be raised by complaint, every trial on such a complaint could become a vehicle for litigating antitrust, securities fraud, and other complex claims for relief in the course of deciding the question of relief from the automatic stay. The secured creditor could be left with a Hobson's choice of litigating the stay, together with the coinplex issues raised by the counterclaim, within a very abbreviated time, or permitting substantial erosion of its secured position while the complex issues are litigated in a more normal manner. In order to avoid this result, the proposed redrafting of section 362 reverts to the pre-Bankruptcy Rules procedure, and requires that requests for rehef from stay be made by motion. This eliminates the possibility of complicating the proceeding with evidence beyond that needed to determine the equities involved in either granting or denying relief from the stay.

2. The proposed redrafting of 362 adopts from the present Bankruptcy Rules both the requirement that the party opposing relief froin the stay carry the burden of showing an entitleinent to continuation of the stay and also the requirement that requests for relief froin the bankruptcy stay be given calendar priority by the bankruptcy court. ${ }^{245}$

3. Section 362(e) of H.R. 8200 provides, in effect, that the bankruptcy stay will continue so long as no party in interest requests that it be terminated. It further provides, however, that the stay will automatically terminate thirty days after a party in interest serves notice of a motion for relief from the stay, unless the stay is continued by order of the court after a proper hearing. The court inay, of course, continue the stay in effect after a final hearing on a motion brought under subsection (d). It may not be possible, however, for the court to rule on a motion under subsection (d) before the stay would autornatically terminate under subsection (e) thirty dnys after service of the inoving papers. Therefore, subsection (e) sets up an alternative procedure, providing for a preliminary hearing at which the court may continue the stay in effect pending the outcome of a fimal hearing under subsection (d).

The redrafting suggested here would modify subsection (e) to prevent certain foreseeable problems froin arising. Under both H.R.

courts shall have original but not exclusive jurisdiction of all civil proceedings arising under title 11 or arising under or related to cases under title 11.

(c) Subsection (b) of this section does not prevent a bankruptcy court, in the interest of justice, from abstaining from hearing a particular proceeding arising under title 11 or arising under or related to a case under title 11 . Such abstention, or a decision not to abstain, is not reviewable by appeal or otherwise.

Title 11 refers to the reorganization Chapter of H.R. 8200.

245. See BANKRUPTCY RULEs 401 (d), 601(c), 8-501(c), 9-4(c), 10-601(c), 11-44 (d), 12-43(d), and 13-401(d). 
8200 and the proposed redrafting, if a final hearing under subsection (d) has been scheduled for a date within thirty days after service of the moving papers, a party opposing rehef from the stay may still notice a motion for a preliminary hearing under subsection (e). The redrafting, however, requires that the preliminary hearing be set for the same time as the previously scheduled final hearing. This provision is designed to prevent parties who oppose relief from the stay from scheduling a preliminary hearing under subsection (e) before the scheduled final hearing under subsection (d), thus gaining a tactical advantage by forcing the court initially to order continuation of the stay. Second, it is designed to prevent parties seeking relief from the stay from attempting to outınaneuver their adversaries by schedulmg a final hearing for a date within thirty days of the service of the moving papers and then taking the hearing off calendar at the last minute, thereby allowing the stay to terminate automatically.

4. Subsection ( $f$ ), as redrafted, is an adaptation of the current Bankruptcy Rule provision for ex parte relief from a stay. ${ }^{246}$ There are two principal changes. First, it eliminates the requirement, contained in the present Bankruptcy Rules, that a complaint seeking relief from stay must be filed before ex parte relief can be granted. Second, by begiuning with the words "in exceptional circunstances," subsection (f), as redrafted, inakes it clear that it is not intended to be used primarily for ex parte relief, but for relief in extraordinary circumstances.

5. Subsection (g), as it exists in H.R. 8200 , provides that the party opposing relief froin the stay has the burden of proof on the issue of adequate protection. ${ }^{247}$ The suggested redrafting of subsection $(\mathrm{g})$

246. See BANKRUPTCY RULES 601(d), 8-501(d), 10-601(d), 11-44(e), 12-43(e), and 13-401(e).

247. The issue of "adequate protection" is treated in $\$ 361$ of H.R. 8200, which reads as follows:

\$ 361. Adequate protection

When adequate protection is required under section 362,363 , or 364 of this title of an interest of an entity in property, such adequate protection may be provided by-

(1) requiring the trustee to make periodic cash payments to such entity, to the extent that the stay under section 362 of this title, use, sale, or lease under section 363 of this title, or any grant of a lien under section 364 of this title results in a decrease in the value of such entity's interest in such property;

(2) providing to such entity an additional or replacement lien to the extent that such stay, use, sale, lease, or grant results in a decrease in the value of such entity's interest in such property;

(3) entitling such entity to compensation allowable under section 503(b) (1) of this title as an admimistrative expense, to the extent that such stay, use, sale, lease, or grant results in a decrease in the value of such entity's interest in such property, if the estate will contain sufficient assets to pay such administrative expense in the event of liquidation of 
clarifies the standard of adequate protection by changing it from a mere burden of proof to a substantive requirement. Termmation of the stay is required unless the court is satisfied that adequate protection has been provided for a party seeking relief from the stay. This is designed to protect the constitutional right of a secured creditor to preserve the value of his collateral. ${ }^{248}$

\section{CONCLUSION}

When a debtor commences proceedings under the Bankruptcy Act, creditors are automatically stayed, under the Bankruptcy Act and Rules, from taking action outside the bankruptcy court to collect the debt owed to them. Secured creditors are stayed from enforcing their security interests, and in order to reach their security, creditors must file a complaint with the bankruptcy court in order to obtain relief from the stay. Whether to grant relief from the stay is a discretionary decision under the equitable powers of the bankruptcy court. In straight bankruptcy proceedings the issues are simple: If there is no equity im the encumbered property that can be realized for the benefit of the debtor's unsecured creditors, relief from the stay should be granted. In Chapter proceedings, exercise of the court's discretion should be guided by a consideration of four factors: (1) Whether there is equity for the debtor in the property that is subject to the creditor's security interest; (2) whether the creditor will suffer material harm as a result of continuation of the stay; (3) whether the property is necessary for continuation of the debtor's business; and (4) whether the debtor lias reasonable prospects of confirming a successful rehabilitation plan.

Several issues have been raised about the nature of proceedings on a complaint for relief from stay, but the authors believe that many misconceptions result from labelimg such proceedings as "adversary proceedings" under the Bankruptcy Rules. While, for purposes of procedural regularity, the court hearing may take the form of a "trial" on a "complaint," that hearing is, in substance, similar to a hearing on a motion for a preliminary injunction. The debtor's right to raise affirmative defenses and counterclaims is therefore limited, and the evidentiary rules governing the "trial" should not be unduly strict.

the debtor; or

(4) granting such other relief as will result in the realization by such entity of the value of such entity's interest in such property.

248. See Wright v. Union Cent. Ins. Co., 311 U.S. 273 (1940); Wright v. Vinton Branch of the Mountain Trust Bank of Roanoke, 300 U.S. 440 (1937); Louisville Joint Stock Land Bank v. Radford, 295 U.S. 555 (1935). 
In addition, there are limitations on the juridiction of the bankruptcy court under the current Bankruptcy Act that prevent proceedings for relief from stay from becoming overly complicated and imtertwined with peripheral disputes between the debtor and secured creditor. Proposed legislation of H.R. 8200, which would completely revise the bankruptcy law of this country, would remove the jurisdictional restraints contained in the present Act, and proceedings for relief from bankruptcy stays could become nightmares of complexity. The authors, therefore, propose a revision of the automatic stay provision of H.R. 8200 that would, among other things, obviate the need to file a formal "complaint" in order for the secured creditor to obtain relief. 